\title{
La presencia eucaristica en los retablos novohispanos: el caso del "colateral" de san Francisco Javier en Tepotzotlán
}

\author{
The Eucharist in the Altarpieces of New Spain: \\ the Case of the "Collateral" of San Francisco Javier in Tepotzotlán
}

Artículo recibido el 7 de septiembre de 20I7; devuelto para revisión el 24 de enero de 20I8; aceptado el I2 de septiembre de 20I8, http://dx.doi.org/IO.2220I/iie.I8703062e.20I9.II4.2667

Guillermo Arce gmo.arce@gmail.com

Líneas de investigación Arte novohispano; retablística y escultura; arte virreinal en la región de Chalco; imágenes de culto.

Lines of research Art of New Spain; altarpieces and sculpture; art of the Viceroyalty, Chalco; sacred images.

Publicaciones más relevantes "Descripción para un retablo novohispano pintado sobre tela/ Beschreibung für ein auf Leinwand gemaltes Retabel (Neuspanien)", en Miradas. Elektronische Zeitschrift für Iberische und Ibero-amerikanische Kunstgeschichte/Revista Digital de Historia del Arte y la Cultura Ibérica e Iberoamericana, núm. I (20I4): I58-162.

Resumen Este artículo llama la atención sobre la importancia de los retablos para el culto eucarístico. El caso que se analizará es el retablo de san Francisco Javier en el templo del noviciado jesuita de Tepotzotlán, hoy Museo Nacional del Virreinato. El manifestador de ese retablo — la exposición de la hostia consagrada - tiene una pintura de la Virgen de Guadalupe, que se ocultaba y desaparecía cuando la Eucaristía se manifestaba. Este artículo discute la posibilidad que el ángel a los pies de la Guadalupana haya sido identificado con el arcángel Miguel.

Palabras clave Liturgia; Miguel Cabrera; hostia consagrada; Virgen de Guadalupe; arcángel san Miguel.

Abstract This article draws attention to the importance of altarpieces for Eucharistic worship. The case that will be analyzed is the altarpiece of San Francisco Javier in the Jesuit novitiate temple of Tepotzotlán, today at the Museo del Virreinato. The altarpieces' ostensory, - monstrance of the consecrated host - holds a painting of the Virgin of Guadalupe, that appeared and disappeared when the Eucharist manifested itself. This article proposes the angel at the feet of the Guadalupana might have been identified with the archangel Michael.

Keywords Liturgy; Miguel Cabrera; consecrated host; Virgin of Guadalupe; archangel Michael. 
DOI: http://dx.doi.org/10.22201/iie.18703062e.2019.114.2667

\author{
GUILLERMO ARCE
}

\title{
La presencia eucarística en los retablos novohispanos: el caso del "colateral" de san Francisco Javier en Tepotzotlán
}

os retablos novohispanos son un tema afortunado sobre el que se han publicado numerosos trabajos. Buena parte de lo escrito sobre ellos busca distinguir y diferenciar tipologías, mismas que han permitido aproximarse a la época de su construcción. Por ello, se le ha concedido gran importancia a los soportes utilizados — $\mathrm{O}$ a su ausencia—, y es el tipo de columna o pilastra lo que facilita formular una nomenclatura para las diferentes etapas de la retablística novohispana (retablos salomónicos, estípite, anástilos, neóstilos, etc.). En la historiografía del arte virreinal ha sido un lugar común referirse a la importancia del Retablo de los Reyes de la Catedral de México, pues esa obra monumental ejerció una influencia decisiva en el arte virreinal del siglo xviII, ya que fue el primer retablo novohispano "estructurado a partir de cuatro pilastras estípites exentas de orden monumental" ${ }^{I}$ Jerónimo de Balbás, su autor, es considerado, por tal razón, uno de los artistas clave para el desarrollo del arte de la Nueva España. Además de él, otro artífice que ha sido señalado para explicar el curso que siguió la retablística de esa centuria es Felipe de Ureña, originario de Toluca, que desarrolló su actividad en diferentes ciudades

I. Martha Fernández, "Tipologías del retablo novohispano (una aproximación)", en $8^{\circ}$ Coloquio del Seminario de Estudio del Patrimonio Artístico. Conservación, Restauración y Defensa. Retablos: su restauración, estudio y conservación (México: Universidad Nacional Autónoma de México-Instituto de Investigaciones Estéticas, 2003), 49. 
de la geografía del virreinato, y a quien Guillermo Tovar de Teresa mencionó como el "difusor del estípite" en el virreinato. ${ }^{2}$

En las recientes décadas se han publicado algunos trabajos en los que se reconocen otras tipologías o categorías de los retablos virreinales. Clara Bargellini apunta que los retablos pueden ser "narrativos" — cuando se observa en ellos una secuencia de pinturas o relieves que narran la Pasión, la vida de la Virgen o un santo en particular - o "icónicos" — cuando únicamente se observan las imágenes de los santos, al portar sus atributos entre las manos. ${ }^{3}$ Asimismo, Martha Fernández diferencia los tipos de plantas (retablos de "corte planimétrico" o "abiombados"), ${ }^{4}$ y también propone algunas tipologías de carácter simbólico. Para ella, los retablos de planta trapezoidal — como los retablos mayores de Huejotzingo y Xochimilco - están asociados al nombre de Cristo, los retablos exentos — como el desaparecido retablo mayor de la catedral de Puebla— representan la Jerusalén celeste, y los retablos hornacina —entre ellos el propio Retablo de los Reyes de la Catedral Metropolitana— representan la caverna sagrada. ${ }^{5}$

2. Sobre Felipe de Ureña existen diferentes publicaciones, como el artículo de José Vergara Vergara, "El taller de Felipe de Ureña", Boletín de Monumentos Históricos, núm. 5 (198I): 35-50. Posteriormente, Tovar de Teresa ańadió nuevas noticias sobre ese artista en diferentes publicaciones. En particular, se sugiere la lectura de Guillermo Tovar de Teresa, "Nuevas investigaciones sobre el barroco estípite", Boletín de Monumentos Históricos, núm. Io (I990): 2-23, puesto que la mayoría de los hallazgos que ese investigador realizó sobre Ureña están reunidos ahí. Clara Bargellini también se ha ocupado de la obra de dicho artífice: Clara Bargellini, "Escultura y retablos coloniales de la ciudad de Durango", Anales del Instituto de Investigaciones Estéticas XV, núm. 59 (1988): I5I-174, y La Catedral de Saltillo y sus imágenes (México: Universidad Nacional Autónoma de México-Instituto de Investigaciones Estéticas/Gobierno del Estado de CoahuilaInstituto Coahuilense de Cultura/Universidad Autónoma de Coahuila, 2005), 54-40. Entre las recientes publicaciones sobre Felipe de Ureña deben destacarse el libro de Fátima Halcón, Felipe de Ureña. La difusión del estípite en Nueva España (Sevilla: Universidad de Sevilla, 20I2), y el artículo de José Armando Hernández Soubervielle y Omar López Padilla, "Juan García de Castañeda, Felipe de Ureña y el proyecto del retablo mayor para el Santuario de Nuestra Señora de San Juan de los Lagos", Anales del Instituto de Investigaciones Estéticas XXXVI, núm. IO5 (20I4): 63-93.

3. Clara Bargellini, "Monte de oro y nuevo cielo: composición y significado de los retablos novohispanos", en Estudios sobre arte. Sesenta años del Instituto de Investigaciones Estéticas, eds. Martha Fernández y Louise Noelle (México: Universidad Nacional Autónoma de México-Instituto de Investigaciones Estéticas, 1998), I27-I35.

4. Fernández, "Tipologías", 35-57.

5. Martha Fernández, "El significado simbólico del retablo novohispano. Tres tipologías", en Estudios sobre el simbolismo en la arquitectura novohispana (México: Instituto Nacional de Antropología e Historia/Universidad Nacional Autónoma de México, 201I), 305-328. Véase también: Martha Fernández, "El retablo como imagen del paraíso", en Investigaciones sobre escultura y pin- 
No es el propósito de los párrafos precedentes hacer una revisión exhaustiva de la historiografía de los retablos novohispanos. Más bien, se ha querido señalar los principales caminos recorridos en su investigación y, para el objetivo del presente artículo, hacer evidente que aún no se ha explorado la relación de los retablos con la liturgia, es decir, con las ceremonias de la fe católica que se celebran siguiendo un protocolo muy estricto. $\mathrm{Al}$ respecto, se debe mencionar que en los retablos había dos diferentes espacios litúrgicos para la presencia del Santísimo Sacramento. Uno de ellos —al que ahora se suele llamar "sagrario" — se usó para reservar las hostias consagradas, en tanto que el segundo - conocido ahora como "manifestador" - fue el lugar donde se mostraba el Cuerpo de Cristo. A pesar de su importancia, ambos sitios han sido poco valorados por los historiadores del arte novohispano. Como bien se sabe, la Eucaristía es el sacramento instituido por el propio Jesús durante la Última Cena. En cada misa, el sacerdote celebra nuevamente ese sacramento, en el que las hostias y el vino se convierten en el cuerpo y la sangre de Cristo (la transubstanciación).

El caso central que se analizará en las siguientes páginas es el retablo mayor del templo del noviciado jesuita de Tepotzotlán — hoy Museo Nacional del Virreinato-, uno de los retablos virreinales más conocidos para los investigadores e incluso para lectores no especializados, pues se trata de una obra que se ha reproducido en un sinnúmero de publicaciones, una y otra vez (fig. I). Por esa razón, tal vez cause extrañeza que me refiera en este artículo a un retablo tan conocido, pues parecería que no habría nada nuevo que decir sobre él. Sin embargo, la presencia de la Eucaristía en ese retablo aún no ha sido valorada. Por ello, al detener la mirada en el manifestador de ese retablo se reconocerán significados que habían permanecido velados a nuestros ojos.

\section{El retablo mayor de Tepotzotlán: historiografía e interrogantes sobre su "sagrario de torno"}

Uno de los trabajos fundamentales sobre los retablos del templo del noviciado de Tepotzotlán es el libro de María del Consuelo Maquívar, Los retablos de Tepotzotlán, dedicado a la iconografía de los retablos de esa iglesia. ${ }^{6}$ Indu-

tura. Siglos XVI-XVIII, ed. Elisa Vargaslugo (México: Universidad Nacional Autónoma de México-Instituto de Investigaciones Estéticas, 2012), I3-27.

6. María del Consuelo Maquívar, Los retablos de Tepotzotlán, $3^{\text {a }}$ edición (México: Institu- 
dablemente, uno de los principales méritos de la citada autora es haber emprendido el análisis iconográfico de ese conjunto retablístico, cuando los antecedentes de una investigación de ese tipo eran aún escasos en México. Tan sólo unos años después, Guillermo Tovar de Teresa publicó en el Boletín de Monumentos Históricos, el contrato para la fábrica de los tres retablos del presbiterio de la iglesia jesuita - el mayor y dos laterales. El mencionado contrato se suscribió en la capital del virreinato el 7 de diciembre de $1753 .{ }^{7}$ El citado investigador destacó que los autores de esos retablos fueron Miguel Cabrera —uno de los pintores virreinales de mayor renombre- y el ensamblador Higinio de Chávez —artífice totalmente desconocido cuando Tovar publicó el contrato. ${ }^{8}$ El documento dice con claridad que:

Don Miguel de Cabrera, maestro del arte de pintar, e Yginio de Chaves, maestro de ensamblador, vecinos de esta dicha ciudad [...] Dijeron que se obligan, [a] hacer como de facto harán, un colateral o retablo de buena madera, dorado de oro fino, para altar principal de la iglesia de el colegio de la Sagrada Compañía de Jesús de el Pueblo de Teposotlán [...] poniendo maderas y todos los materiales, hasta su total y perfecta conclusión los otorgantes, y asimismo han de hacer y fabricar a la misma correspondencia otros dos retablos laterales pegados e unidos con el principal que cada uno ha de tener de alto quince varas, y de ancho seis varas. ${ }^{9}$

El contrato no precisa en qué consistiría la intervención de Cabrera en la fábrica de los retablos del presbiterio del templo jesuita. Tovar de Teresa consideró que el pintor pudo haber diseñado el retablo mayor, aseveración repetida por

to Nacional de Antropología e Historia, 1984). La primera edición de este libro se publicó en I976, y la segunda, en 1982 .

7. Guillermo Tovar de Teresa, "Los autores de los retablos de la iglesia del colegio de Tepotzotlán”, Boletín de Monumentos Históricos, núm. 5 (198I): 29-34.

8. Hasta ahora sólo ha sido hallado el contrato para la construcción de los tres retablos del presbiterio del templo del noviciado jesuita de Tepotzotlán. Aún se desconoce quiénes fueron los autores del resto de los retablos de esa iglesia, aunque es posible que también hayan sido Miguel Cabrera e Higinio de Chávez. Hoy se sabe que Chávez fue un artista cercano a José Joaquín de Sáyagos. Ambos artífices fueron contratados en 1749 para fabricar el desaparecido retablo mayor del templo del colegio de San Francisco Javier en Puebla de los Ángeles. Guillermo Tovar de Teresa dio a conocer ésta y otras noticias sobre Higinio de Chávez en "Nuevas noticias sobre Higinio de Chávez y José Joaquín de Sállagos, el autor del retablo mayor de Vizcaínas en 1752", en Noticias sobre el retablo mayor de Tepotzotlán (México: Antigua Librería Robredo, 1985), 27-47.

9. Tovar de Teresa, "Los autores", 33. 


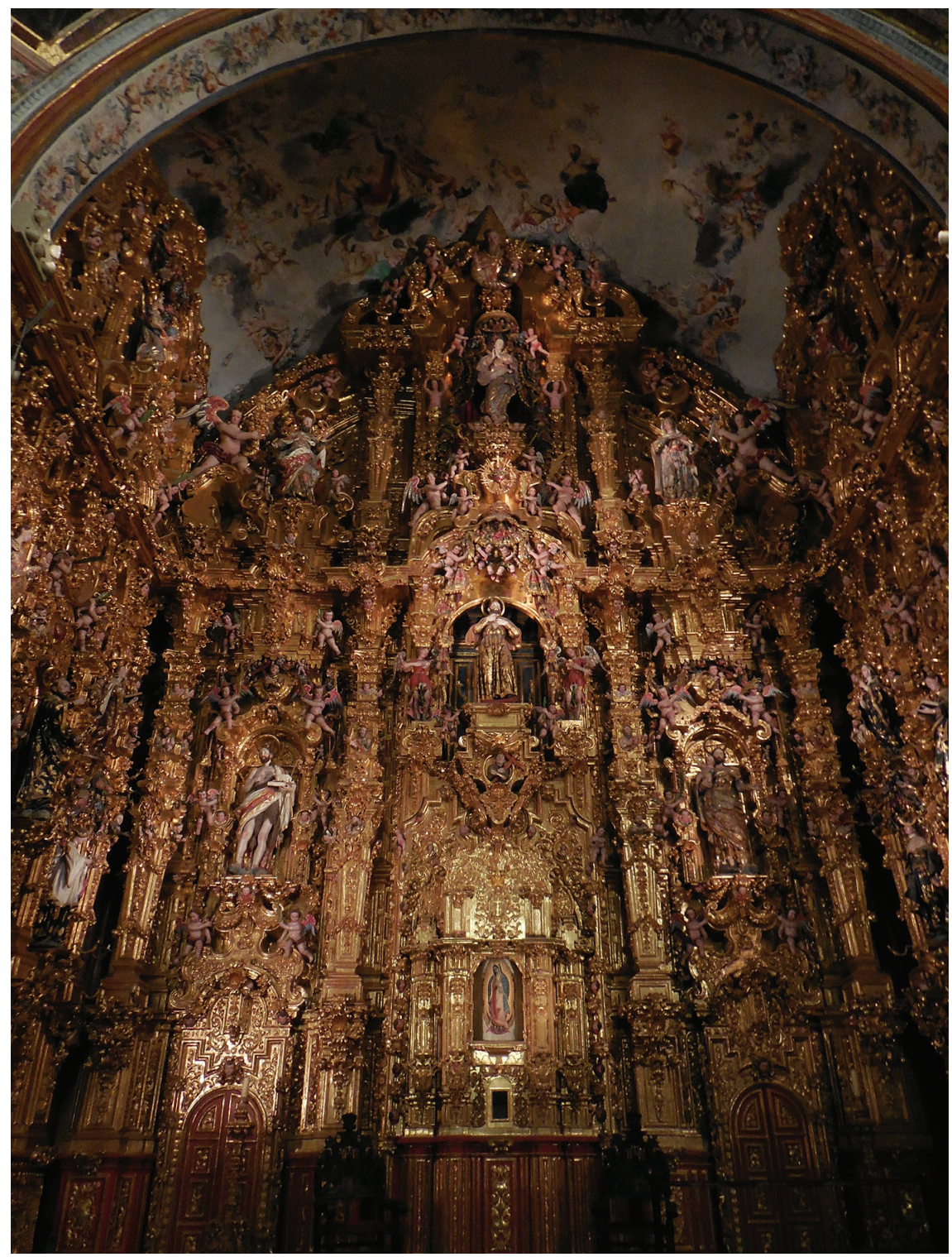

I. Miguel Cabrera e Higinio de Chávez, retablo de san Francisco Javier, contratado el 7 de diciembre de 1753 y posiblemente estrenado el 3 de diciembre de 1754, Museo Nacional del Virreinato, Tepotzotlán. Foto: Guillermo Arce. Secretaría de Cultura.-INAH. Méx."Reproducción autorizada por el Instituto Nacional de Antropología e Historia". 
diferentes autores. Sin embargo, es posible que el taller de Cabrera haya realizado el dorado y la policromía de sus esculturas, pues el contrato señala que el pintor e Higinio de Chávez deberían realizar un "retablo de buena madera, dorado de oro fino".

El contrato especifica que:

los mencionados tres colaterales los darán concluidos [y] perfectamente acabados el día fin de el mes de noviembre del año próximo venidero de mil setecientos cincuenta y cuatro para que se estrenen el día tres del siguiente mes o por diciembre que es el de el señor san Francisco Xavier y el día en que se celebra. ${ }^{\text {IO }}$

Las maderas para la obra provendrían de la capital del virreinato, desde donde serían trasladadas con "mulas, bueyes y operarios" hasta el pueblo de Tepotzotlán, en donde se fabricarían los tres colaterales. Asimismo, el rector del noviciado, el padre Pedro Reales, indicaría a Cabrera y Chávez "las cosas particulares que han de ejecutar de los lienzos, estatuas y medallones por no tener presente cuántas menudencias se pudieran expresar". ${ }^{\text {II }}$

Además, en el contrato se indican las características de esos aparatos dorados. En el caso del retablo mayor se especifican dimensiones, número de esculturas y modelos. De acuerdo con el documento, ese retablo debería ser:

de diez y ocho varas de alto, y doce varas de ancho, con siete estatuas, al modelo y hechura de el que está y se halla en el altar mayor de la iglesia parroquial de Santa Catharina Mártir de esta ciudad, mejorando el que han de fabricar en cuanto se pueda, con cien albortantes de metal, y el sagrario de torno en el que han de ir los siete príncipes, y ha de ser de la hechura del que está ejecutado en la casa o recogimiento de las Vizcaínas. ${ }^{\text {I2 }}$

La mención de los modelos para la realización del retablo mayor de Tepotzotlán es de enorme interés, pero lamentablemente no es posible hacer comparaciones con los arquetipos. El retablo de la parroquia de Santa Catarina Mártir ya no existe, ${ }^{\mathrm{I3}} \mathrm{y}$ el retablo principal de las Vizcaínas —obra de José Joaquín de

Io. Tovar de Teresa, "Los autores", 33.

II. Tovar de Teresa, "Los autores", 34

I2. Tovar de Teresa, "Los autores", 33.

I3. El retablo mayor de la parroquia de Santa Catarina Mártir fue fabricado por Felipe de Ureña, de acuerdo con un contrato firmado el 28 de junio de I737, el cual publicó Guiller- 
Sáyagos — ${ }^{14}$ ha sufrido modificaciones de importancia en el transcurso de su existencia, entre ellas, la destrucción de su "sagrario"; esto ocurrió cuando se construyó un baldaquino de estilo neoclásico delante de él, el cual se puede observar en fotografías antiguas (fig. 2)..$^{\text {Is }}$

En el caso del retablo mayor de Tepotzotlán, el "sagrario de torno" mencionado en el contrato es el espacio que tiene una imagen pictórica de la Virgen de Guadalupe, a la que es posible desplazar para mostrar el interior del mismo (fig. 3). La pintura no está firmada, pero es posible inferir que salió del pincel de Miguel Cabrera, no sólo por hallarse en un retablo para cuya realización se le contrató, sino también porque su calidad obliga a pensar que fue ejecutada por un pintor de primera línea. Pero además, al observar con atención la vestimenta de esa Guadalupana se advertirá que hay un "ocho" en su túnica, arriba de su pie derecho.

El origen de ese número se haya en el propio ayate de Juan Diego, el cual se inspeccionó el 30 de abril de I75I. En aquella ocasión, el propio Cabrera y seis colegas suyos inspeccionaron la imagen mariana. El examen permitió a Cabrera "confirmar medidas, realizar templas sobre los colores y hacer un minucioso estudio de la técnica y sus materiales". ${ }^{16}$ Como resultado de aquella revisión, el pintor escribió un dictamen que se publicó cinco años después, en el que llamó la atención sobre un número en la tilma, el cual había pasado inadvertido hasta ese entonces. De acuerdo con el propio Cabrera, en la túnica de la Virgen, "sobre el pie derecho [...] tiene un número ocho índice". ${ }^{17}$ En opi-

mo Tovar de Teresa, "El retablo mayor de Santa Catarina Mártir, Cuadernos de Arte Colonial, núm. 2 (1987): 77-83. En ese documento se estipula que el paradigma para la construcción de ese retablo debería ser "idéntico en la fachada y licimiento [įlucimiento?] (según se ha pactado) como el principal retablo de la capilla del venerable orden de penitencia de nuestro Seráfico Padre San Francisco de esta corte". Por desgracia, el retablo mayor de la Tercera Orden tampoco existe.

I4. El contrato para la fábrica del retablo mayor de Vizcaínas también lo dio a conocer Tovar de Teresa, Noticias, 45-47. El documento se suscribió el 17 de octubre de 1752, es decir, poco más de un ańo antes de que se firmara el contrato para la construcción de los retablo del presbiterio de Tepotzotlán. En dicho documento, José Joaquín de Sáyagos se comprometió a terminar el retablo de Vizcaínas — incluyendo el dorado y el estofado de sus esculturas - en un plazo de "ocho meses y medio".

I5. El baldaquino destruido se puede observar en una fotografía tomada alrededor de 1915, la cual forma parte de la Colección Archivo Casasola-Fototeca Nacional del INAH.

I6. Jaime Cuadriello, "Cifra, signo y artilugio: el 'ocho' de Guadalupe”, Anales del Instituto de Investigaciones Estéticas XXXIX, núm. IIO (2017): I60.

17. Miguel Cabrera, Maravilla americana, y conjunto de raras maravillas observadas con la direc- 


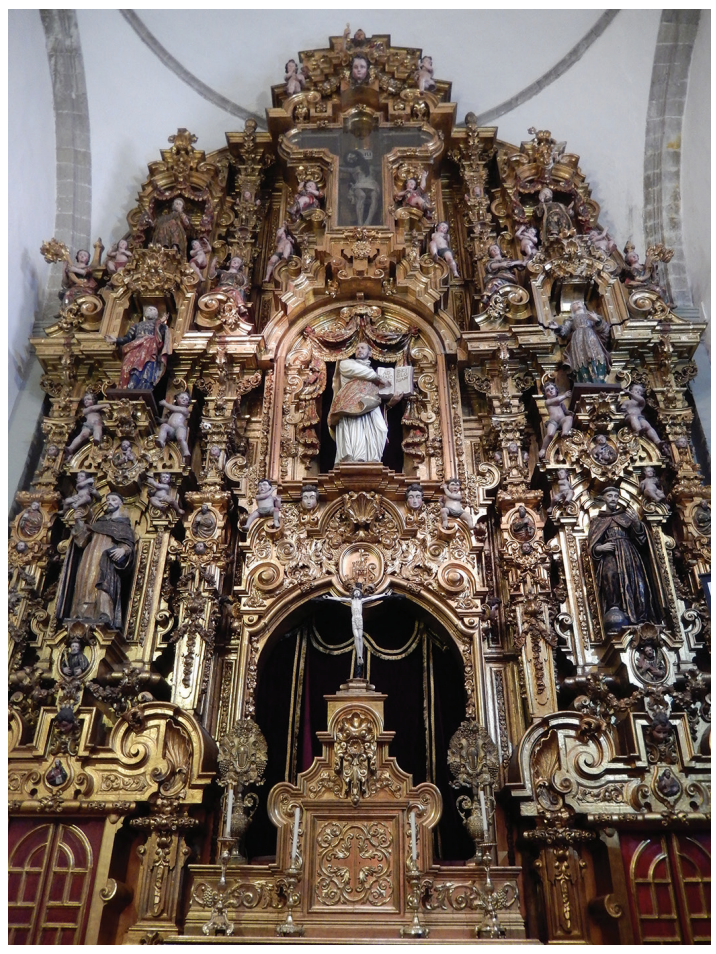

2. José Joaquín de Sáyagos, retablo de san Ignacio de Loyola, contratado el i7 de octubre de I752, capilla de las Vizcaínas, Ciudad de México. Foto: Guillermo Arce.

nión del artista, aquella cifra "nos acuerda, que su portentosa, y primera aparición fue dentro de la Octava de su Concepción Purísima, de cuyo misterio es la más fiel y ajustada copia" ${ }^{18}$ A partir de la inspección de I75I, en diferentes copias de la Virgen del Tepeyac, salidas tanto del pincel cabreriano como de otros pintores de la Nueva España, reprodujeron en la túnica de la Virgen ese número. De acuerdo con Jaime Cuadriello:

los historiadores del arte actuales, metidos en la práctica del expertise, hemos podido fechar las copias posteriores a I75I con mayor precisión. Ya que, ciertamente, ni Juan Correa, ni los hermanos Rodríguez Juárez emplearon semejante cifra e incluso para

ción de las Reglas de el Arte de la Pintura en la prodigiosa imagen de Nuestra Señora de Guadalupe de México (México: Imprenta del Real y más Antiguo Colegio de San Ildefonso, I756), 25.

I8. Cabrera, Maravilla americana, 25. 
3. Miguel Cabrera, Virgen de

Guadalupe del retablo de san Francisco Javier, Museo Nacional del Virreinato, Tepotzotlán. Foto tomada de Tepotzotlán, la vida y la obra en la Nueva España, $2^{\mathrm{a}}$ edición (México: Asociación de Amigos del Museo Nacional del Virreinato/Consejo Nacional para la Cultura y las Artes-Instituto Nacional de Antropología e Historia/Fundación BBVA Bancomer, 2003), 42.

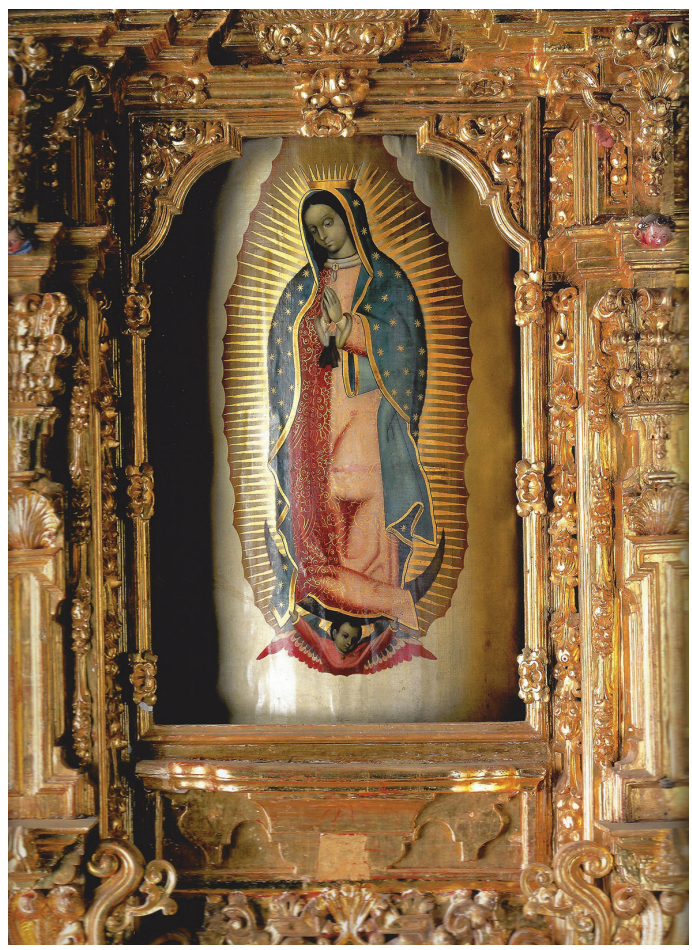

otros artistas, ajenos a la interpretación de Cabrera, no dejaría de ser un manchón que afearía el conjunto de la obra. ${ }^{19}$

La pintura del manifestador del retablo mayor de Tepotzotlán forma parte de ese linaje de copias del ayate juandieguino que reproducen el "ocho" de la túnica mariana. Y como es evidente, se trata de una de las más tempranas, pues el retablo mayor de Tepotzotlán se contrató casi tres años después de que ocurriera la inspección de la tilma sagrada.

Cabe señalar que tras la inspección del 30 de abril de i75I, Miguel Cabrera regresó casi un año después al Tepeyac. Ahora, el is de abril de I752, el artista en compañía de los pintores José Ventura Arnáez y José de Alzíbar —quienes habían estado presentes de la inspección del 30 de abril de I75I- realizó tres diferentes copias de la Virgen plasmada en la tilma. La primera fue

19. Cuadriello, "Cifra, signo y artilugio", I7I. 
hecha para el arzobispo Manuel Rubio y Salinas, la segunda para el jesuita Juan Francisco López "quien estaba para partirse de procurador a Roma, en donde presentó a nuestro Santísimo Padre [el papa Benedicto XIV] dicha imagen" y la tercera quedó en poder del propio Cabrera, quien la mantuvo "en su casa para beneficio de que se logren otras copias". ${ }^{20}$ Seguramente, la tercera copia fue usada por Cabrera para realizar la Guadalupana del "sagrario de torno".

En su libro ya citado, Maquívar afirmó que el sitio con la pintura de la Virgen de Guadalupe es un "manifestador". ${ }^{21}$ Dicho término lo han usado, sobre todo, los historiadores del arte españoles para referirse al sitio en el que la hostia consagrada se expone a la adoración de los fieles, en una custodia u ostensorio. ${ }^{22}$ En cambio, el término "sagrario", empleado en el contrato, hoy día se utiliza para referirse al lugar donde se guardan las hostias consagradas, en un copón. Podría pensarse que la citada autora confundió el "sagrario" del retablo mayor de Tepotzotlán con un manifestador. Sin embargo, la historiadora del arte está en lo cierto, pues el "sagrario de torno" del retablo del templo jesuita se concibió para la exposición de la hostia consagrada.

\section{El Santísimo Sacramento en los retablos virreinales}

A pesar de que muchísimos de los retablos que se construyeron durante la época virreinal han desaparecido, y de que la inmensa mayoría de los que subsisten han sido modificados o mutilados, hay algunos que aún conservan ambos espacios para la Eucaristía. Entre ellos se encuentra el retablo mayor de la parroquia de Santa Prisca de Taxco, obra del siglo Xvin fabricada por Isidoro Vicente de Balbás (fig. 4). ${ }^{23}$ Ese soberbio retablo tiene un mueble dividido en forma horizontal en tres partes, en dos de las cuales se hayan los sitios para la presencia del Santísimo Sacramento. En el centro de la parte inferior se encuentra el lugar donde se guardan las hostias que se consagran durante la misa, el cual se

20. "Aprobación de D. Joseph Bentura Arnaez", en Maravilla americana, sin número de página.

2I. Maquívar, Los retablos de Tepotzotlán, 34 .

22. Alfonso Rodríguez G. de Ceballos, "Sagrario y manifestador en el retablo barroco español”, Imafronte, núm. I2 (1998): 25-49.

23. Elisa Vargaslugo, La iglesia de Santa Prisca de Taxco, $3^{\text {a }}$ edición (México: Seminario de Cultura Mexicana/Universidad Nacional Autónoma de México-Instituto de Investigaciones Estéticas/Coordinación de Humanidades/Coordinación de Difusión Cultural, 1999), 77-78. 
4. Isidoro Vicente de Balbás, retablo de la Inmaculada Concepción (detalle), siglo xvin, parroquia de Santa Prisca, Taxco. Foto: Guillermo

Arce. Secretaría de Cultura.-INAH. Méx.- "Reproducción autorizada por el Instituto Nacional de Antropología e Historia".

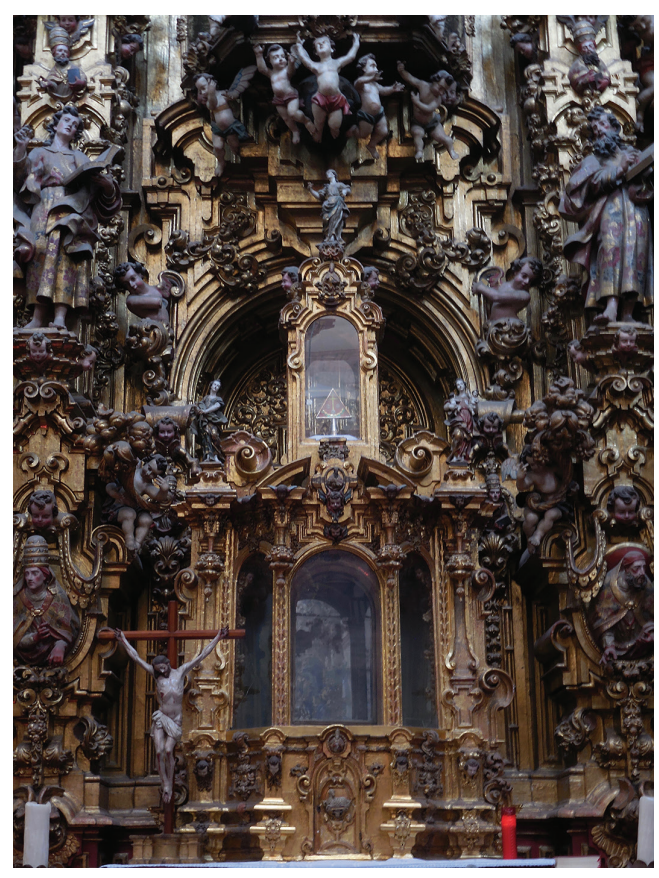

distingue por su pequeńa puerta con cerradura con un relieve que representa al Cordero Sagrado. En ese sitio, las hostias consagradas permanecían ocultas; los fieles sabían que Cristo Sacramento estaba ahí, aunque no podían contemplarlo. Arriba de esa puertecilla hay un espacio de mayores dimensiones en donde se exponía en un ostensorio la hostia consagrada. El sitio se caracteriza por la presencia de espejos en su interior, los cuales reflejaban la luz de las velas que se encendían durante la exposición eucarística. La tercera sección, que se ubica en la parte más alta del mueble, ahora está vacía, pero es posible que originalmente haya alojado una escultura, hoy perdida. Además, debe mencionarse que en ese mueble hay tres diferentes tallas que representan la Fe, la Esperanza y la Caridad.

Por otro lado, al revisar diferentes contratos para la construcción de retablos es posible aproximarse a la terminología usada en aquella época para referirse a ambos espacios. Gracias a esos documentos se sabe que los términos empleados para referirse al sitio de la exposición de la Eucaristía fueron "sagrario" — como 
en el caso del contrato del retablo mayor de Tepotzotlán—y “tabernáculo”. ${ }^{24} \mathrm{La}$ palabra "manifestador", en cambio, al parecer es un término de creación reciente que no fue común en la Nueva Espańa (por lo menos, no hallé el término "manifestador" en las diferentes fuentes primarias revisadas para este artículo). Sin embargo, la expresión "manifestador" deriva de "manifestar", verbo que sí fue usado con gran frecuencia para referirse a la acción de exponer el Cuerpo de Cristo para su adoración.

Curiosamente, los términos "sagrario" y "tabernáculo" también se emplearon para referirse al lugar donde se guardan las hostias consagradas. Además de ambas palabras, existió un vocablo que sólo hacía mención al sitio donde se resguardaban las hostias bajo llave, "depósito", el cual aparece con frecuencia en diferentes contratos. ${ }^{25}$ "Depósito" deriva del verbo "depositar", el cual se usó para referirse a la acción de guardar el Santísimo Sacramento. Ambos términos, prácticamente caídos en desuso, han sido desplazados por las expresiones "reserva" y "reservar". ${ }^{26}$

La palabra "sagrario" incluso se empleó para referirse a muebles que, como el del retablo mayor de Santa Prisca, alojan tanto el sitio para guardar las hostias consagradas como el destinado para la exposición. Como prueba de ello, baste mencionar un documento que describe cómo debería ser el retablo que se construiría para el templo de San Agustín, en Zacatecas. El documento al que me refiero contiene las "condiciones y forma de la obra del retablo que el maestro Andrés de Roa ha de hacer", y se encuentra anexado al contrato suscrito en la Ciudad de México, el I6 de marzo de I $694 .{ }^{27}$ Infortunadamente la obra ya no existe, pero gracias a ese documento es posible saber que en el centro del primer cuerpo debería estar un "sagrario", el cual se describe con cierta amplitud:

24. La misma situación ocurría en España, de acuerdo con la lectura del artículo de Martín González, "Sagrario y manifestador", Imafronte, 25-27.

25. Por ejemplo, véase los contratos transcritos tanto por Elisa Vargaslugo y Gustavo Curiel, Juan Correa. Su vida y su obra. Cuerpo de documentos, t. III (México: Universidad Nacional Autónoma de México-Instituto de Investigaciones Estéticas, 199i), como por María del Rocío Arroyo Moreno, "El retablo del siglo Xviı en la capital de la Nueva España”, tesis de doctorado en Historia del Arte (Ciudad de México: Universidad Nacional Autónoma de México, 2008).

26. José Aldazábal, Vocabulario básico de liturgia, $2^{\mathrm{a}}$ edición (Barcelona: Centre de Pastoral Litúrgica, 1996), 34I.

27. Archivo General de Notarías, Martín del Río, Ciudad de México, i6 de marzo de 1694, núm. 563, f. 226, reproducido en: Vargaslugo y Curiel, Juan Correa, 87-90. 
ha de tener de composición dicho sagrario su banco de seis macizos y seis columnas que son las que contiene el primer cuerpo del sagrario. Su depósito dorado, todo de adentro y en medio con su puerta y llave a donde ha de ir pintado un Pastor con su Cordero en hombros; con más, su cornisa y sotabanco para que reciba el segundo cuerpo a donde ha de ir con dicha orden otras seis columnas. Ha de ir transparente para que se descubra el Santísimo Sacramento, con la medida de la custodia que tiene una vara de hueco; con su cornisamento y tumbilla que remate debajo de dicho arco, con una concha de relieve afuera para el punto del sagrario; que en el principio de la concha ha de ir con dos ángeles en las enjutas. Esto es todo el sagrario. ${ }^{28}$

De acuerdo con esa descripción, el "sagrario" estaba conformado por dos cuerpos. En el centro del primero se ubicaba el "depósito", que debía estar dorado en su interior; y con una puerta con cerradura en la que estaba pintado el Buen Pastor. El segundo cuerpo de ese mueble se destinaba a la exposición de la Eucaristía. Como se ha visto, ese sitio debía fabricarse de acuerdo con la altura de una "custodia" ya existente. Asimismo, siguiendo ese documento, la Sagrada Forma se "descubría" para ser mostrada a los fieles, es decir, la hostia permanecía velada antes de ser expuesta.

El manifestador es un espacio que, hasta donde he podido advertir, sólo se encuentra en los retablos mayores, por lo que el retablo al que me acabo de referir debió haberse ubicado en el muro principal del presbiterio del templo.

\section{El depósito eucarístico}

Las hostias consagradas se reservan en un sitio específico para llevarse a los enfermos, quienes no pueden asistir a misa para comulgar. La costumbre se remonta a las primeras centurias del cristianismo. En el Concilio de Nicea, celebrado en el año 325, se estableció que los agonizantes no deberían morir sin antes haber recibido el "santo viático". ${ }^{29}$ Más de un milenio después, en el Concilio de Trento se confirmó que el Santísimo Sacramento debería seguir siendo reservado para ser llevado a los enfermos:

28. Vargaslugo y Curiel, Juan Correa, 89 (las cursivas son mías).

29. Mario Righetti, Historia de la liturgia, vol. II (Madrid: Biblioteca de Autores Cristianos, I955), 489. 
Es tan antigua la costumbre de guardar en el sagrario la santa Eucaristía, que se conocía en el siglo en que se celebró el concilio Niceno. Es constante, que a más de ser muy conforme a la equidad y razón, se halla mandado en muchos concilios, y observado por costumbre antiquísima de la Iglesia católica, que se conduzca la misma sagrada Eucaristía para administrarla a los enfermos, y que con este fin se conserve cuidadosamente en las iglesias. Por este motivo establece el santo Concilio, que absolutamente debe mantenerse tan saludable costumbre. ${ }^{30}$

Asimismo, se señaló que si "alguno dijere, que no es lícito reservar la sagrada Eucaristía en el sagrario, sino que inmediatamente después de la consagración se ha de distribuir de necesidad a los que estén presentes, o dijere que no es lícito llevarla honoríficamente a los enfermos, sea excomulgado". ${ }^{3 \mathrm{I}}$

En el Concilio de Trento no se señaló en qué parte de los templos debería ubicarse el lugar para depositar las hostias consagradas. Sin embargo, fue en el propio siglo Xvi que cobró importancia la modalidad de conservación eucarística que se conoció en la Nueva España: el depósito integrado al retablo mayor. En el concilio provincial de Milán de 1565 , siendo arzobispo san Carlos Borromeo, se prescribió que:

El arzobispo diligentísimamente cuide que en las iglesias catedral, colegiales, parroquiales y otras cualesquiera donde suele o debe custodiarse la sacrosanta Eucaristía, ésta se coloque en el altar mayor; a menos que le parezca mejor otro por causa necesaria o grave. Ante la misma siempre resplandezca una lámpara encendida. El tabernáculo en que se guarda, sea adornado, bien cerrado y protegido. ${ }^{32}$

Posteriormente, en el Ritual romano, publicado en I6I4 por instrucciones del papa Paulo V, se dice en forma clara que la reserva eucarística se debería colocar "en el centro del altar mayor o, en todo caso, en otro altar que parezca más cómodo y decente a la veneración de dicho Sacramento, de tal manera que no se interponga ningún impedimento a las funciones sagradas o a otros oficios

30. El sacrosanto y ecuménico Concilio de Trento, trad. Ignacio López de Ayala (Madrid: Imprenta Real, I785), I66.

3I. El sacrosanto y ecuménico, 173.

32. Carlos Borromeo, Instrucciones de la fábrica y del ajuar eclesiásticos, introd., trad. y notas, Bulmaro Reyes Coria, nota preliminar, Elena Isabel Estrada de Gerlero, notas contextuales Paola Barocchi (México: Universidad Nacional Autónoma de México-Instituto de Investigaciones Estéticas, 20IO), LXIII, citado en la nota 39 de Paola Barocchi. 
eclesiásticos". ${ }^{33}$ En el mismo documento, además, se insistió que en donde quiera que se hallara la reserva eucarística siempre hubiera una lámpara encendida.

Estas recomendaciones se conocieron en la Nueva España. Por ejemplo, el padre Miguel Venegas, de la Compañía de Jesús, señalaba en su Manual de párrocos que el depósito del Santísimo Sacramento:

ha de estar colocado en el altar mayor, o en otro que pareciese más acomodado y decente para la veneración y culto de tanto Sacramento [sic], de suerte que ningún impedimento se le ocasione con otras funciones u oficios eclesiásticos. Ardan perpetuamente delante de Él de día y de noche muchas lámparas, o a lo menos una. ${ }^{34}$

El ignaciano además recomendaba:

Tenga cuidado el párroco, de que siempre se conserven algunas formas consagradas en tanto número, que basten para el uso de las comuniones de los enfermos y de los demás fieles, las cuales se han de conservar en la píxide o copón, que ha de ser de materia sólida, decente y limpia, que ha de estar cerrado con su tapadera y cubierto con un velo blanco dentro del tabernáculo, que ha de estar adornado cuanto se pudiere, y cerrado con llave. 35

\section{La exposición eucarística}

A diferencia del "depósito", que se caracteriza por la presencia continua de la Eucaristía, la hostia consagrada sólo se manifiesta en ocasiones muy específicas. A diferencia de la reserva eucarística, cuyos antecedentes se remontan a los primeros siglos del cristianismo, la exposición del Santísimo Sacramento, ya fuera en procesiones o dentro de los templos, sólo ocurrió siglos después, hasta la Baja Edad Media. Más adelante, en el siglo xvi durante el Concilio de Trento, se prescribió que el Cuerpo de Cristo debería seguir siendo expuesto a los fie-

33. Citado por Alfonso Rodríguez G. de Ceballos, "Liturgia, culto y arquitectura después del Concilio de Trento: la situación de México durante los siglos xvir y xviII", Boletín del Museo e Instituto Camón Aznar, núms. 48-49 (I992): 287-288.

34. Miguel Venegas, Manual de párrocos para administrar los Santos Sacramentos y exercer otras funciones eclesiásticas conforme al Ritual romano (México: Joseph Bernardo de Hogal, Ministro e Impresor del Real y Apostólico Tribunal de Santa Cruzada, I73I), 53.

35. Venegas, Manual de párrocos, 53. 
les: "Si alguno dijere, que en el santo Sacramento de la Eucaristía no se debe adorar a Cristo hijo unigénito de Dios con el culto de latría [...] o que no se debe exponer públicamente al pueblo para que le adore, y que los que le adoran son idólatras, sea excomulgado". ${ }^{36}$

Una de las celebraciones en las que se expone el Cuerpo de Cristo son las Cuarenta Horas, cuyo origen se remonta a la primera mitad del siglo XVI, en Italia. En 1527, en la iglesia del Santo Sepulcro de Milán, un misionero llamado Gian Antonio Bellotti exhortó a los fieles a que oraran ante la Eucaristía durante cuarenta horas continuas, en recuerdo de las que permaneció el cuerpo de Jesucristo en el sepulcro. La naciente devoción fue introducida en Roma hacia 1550 gracias a san Felipe Neri, y en 1592, mediante la constitución Graves et diuturnae, el papa Clemente VIII estableció: "Nos hemos decretado el establecer oficialmente en esta ciudad una cadena ininterrumpida de plegarias, por la cual, en diversas iglesias y en determinados días, se celebre la piadosa y saludable devoción de las Cuarenta Horas, de forma que en cada hora del día y de la noche en todo el año suba continuamente al trono de Dios el incienso de la plegaria”. ${ }^{37}$ El pontífice señaló además que la devoción de las Cuarenta Horas tenía como finalidad lograr la concordia entre los príncipes cristianos y la paz entre la naciones.

Las Cuarenta Horas no se conocieron en la Nueva España sino hasta los albores del siglo xviII, y así lo informa una Carta Pastoral del arzobispo Alonso Núnez de Haro y Peralta, impresa en 1785. De acuerdo con ella, "la Oración famosa de Cuarenta Horas [era] llamada vulgar y abusivamente Jubileo circular", ${ }^{38}$ y se menciona que nació "en memoria de las que estuvo en el sepulcro nuestro Redentor", 39 y que "fue instituida perpetuamente en Roma por el Sumo Pontífice Clemente VIII en 25 de noviembre de 1592 ". ${ }^{\circ}$ De acuerdo con la Carta Pastoral, el "Jubileo Circular" se instituyó en la capital del virreinato mediante un edicto del arzobispo Juan de Ortega Montañés, del 7 de enero de 1707. La carta, además, informa que el Santísimo Sacramento no se expo-

36. El sacrosanto y ecuménico, $172-173$.

37. Citado por Righetti, Historia de la liturgia, vol. II, 545 .

38. Alonso Núnez de Haro y Peralta, Nos el Dr. D. Alonso Núnez de Haro y Peralta por la gracia de Dios y de la Santa Sede Apostólica Arzobispo de México del Consejo de S. M, Éc.... Hacemos saber, que la Oración famosa de cuarenta horas, llamada vulgar y abusivamente Jubileo circular... (México: s. e., 1785), 2.

39. Núñez de Haro y Peralta, Nos el Dr. D. Alonso Núñez de Haro y Peralta, 2-3.

40. Núñez de Haro y Peralta, Nos el Dr. D. Alonso Núñez de Haro y Peralta, 3. 
nía durante cuarenta horas continuas, sino que ese periodo de tiempo se distribuía en tres días.

La Carta Pastoral tuvo como principal finalidad informar a los fieles que el papa Pío VI había expedido dos breves en torno a la celebración de las Cuarenta Horas en la Ciudad de México. De hecho, en la carta se transcriben ambos documentos. En el primero de ellos, del 9 de marzo de I782, se lee:

PÍO VI. Papa, para perpetua memoria. Habiéndosenos informado que en las iglesias así seculares como regulares de la Ciudad de México en las Indias, se ha establecido la piadosa y saludable Oración de Cuarenta Horas, a semejanza de la que instituyó nuestro predecesor de feliz recordación Clemente Papa VIII en la Ciudad de Roma [...] y que continuamente se celebra guardando cierta distribución de iglesias y tiempo, para que de día y de noche, a todas horas y en todo el año, el incienso de la oración suba a la presencia del Señor [...] Nosotros [...] concedemos misericordiosamente en el Señor indulgencia plenaria y remisión de todos sus pecados a todos y cada uno de los fieles de Christo de uno y otro sexo que verdaderamente arrepentidos, confesados y alimentados del Santísimo Sacramento de la Eucaristía asistieren devotamente en cualquiera iglesia de dicha Ciudad de México en las Indias, en que se celebrare dicha Oración de Cuarenta Horas. ${ }^{41}$

El segundo breve papal es una corrección del primero, y en él se precisa que el Santísimo Sacramento no debería ser expuesto durante cuarenta horas continuas:

Pero habiéndonos informado que en la presente situación y estado de las cosas, de ninguna manera conviene el concurso de dichos fieles en el tiempo de la noche a las expresadas iglesias para conseguir la indulgencia. Queremos con autoridad apostólica, y concedemos por el tenor de las presentes, que nuestras antecedentes mencionadas letras surtan todo su efecto, aunque la oración de cuarenta horas instituida en dichas iglesias se interrumpa en el tiempo de la noche, no obstante cualquiera otra cosa en contrario. ${ }^{42}$

Núñez de Haro y Peralta hizo, además, algunas indicaciones sobre la forma como debería celebrarse la oración de Cuarenta Horas a partir de la publicación

4I. Núñez de Haro y Peralta, Nos el Dr. D. Alonso Núñez de Haro y Peralta, 6-8.

42. Núñez de Haro y Peralta, Nos el Dr. D. Alonso Núñez de Haro y Peralta, 9-Io. 
de la Carta Pastoral. Primeramente, las Cuarenta Horas ya no se distribuirían en tres días, sino en cuatro. El Santísimo Sacramento debería exponerse diez horas cada día, "exponiéndose siempre con misa a las siete de la mañana, y reservándose a las cinco de la tarde con solemnidad y decoro que corresponde". ${ }^{43}$ Asimismo, el prelado indicó en qué días del calendario litúrgico debería suspenderse la celebración: "desde el Domingo de Ramos hasta después de pasados los tres días de Pascua, la octava del Corpus y también el día de Todos los Santos y el de la Conmemoración de los fieles difuntos". ${ }^{44} \mathrm{Se}$ estableció, además, que no deberían celebrarse las Cuarenta Horas en templos en los que no se contara con un sitio para reservar la Eucaristía: "Que en las iglesias, ermitas o capillas en que no haya depósito del Santísimo no entre esta Oración [de Cuarenta Horas], ni se entiendan en el número de las señaladas para la indulgencia circular, ni en ellas se permita exponer al Sacramento". ${ }^{45}$

Hasta ahora, las noticias publicadas sobre la celebración de las Cuarenta Horas en las Nueva España son mínimas. Recientemente, Alena Robin se ha referido a la celebración del Jubileo Circular en la capillas del Vía Crucis de la Ciudad de México. Las capillas se habían edificado entre i684 y I706, siendo la principal promotora de su construcción la Tercera Orden franciscana. De acuerdo con las investigaciones de Robin, el Jubileo Circular se celebró por primera vez en la capilla del Calvario - la cual reunía las últimas tres estacioneshacia 1709, es decir, dos años después de que comenzara a realizarse en la capital del virreinato. ${ }^{46} \mathrm{La}$ festividad se efectuaba en la capilla del Calvario durante tres días. Un documento transcrito en parte por Robin proporciona noticias sobre cómo se celebraban las Cuarenta Horas de exposición de la Eucaristía en la capilla del Calvario. Un día antes de que iniciara la celebración, un sacerdote de la cercana parroquia de la Santa Veracruz decía misa para consagrar la hostia que

43. Núñez de Haro y Peralta, Nos el Dr. D. Alonso Núñez de Haro y Peralta, iI.

44. Núñez de Haro y Peralta, Nos el Dr. D. Alonso Núñez de Haro y Peralta, I2.

45. Núñez de Haro y Peralta, Nos el Dr. D. Alonso Núnez de Haro y Peralta, I2. Ninguno de los dos breves papales dice cuánto tiempo se debería permanecer orando ante la Eucaristía para obtener la indulgencia plenaria, por lo que Alonso Núnez de Haro y Peralta dispuso: "Declaramos, que rezando cada uno de los fieles atenta y devotamente en la iglesia que se celebrare dicha Oración de cuarenta horas a lo menos una Estación Mayor al Santísimo, que son seis Padres nuestros, seis Aves Marías y seis Gloria Patri, y estando verdaderamente arrepentidos, confesados [...] y comulgados espiritual y sacramentalmente [...] ganarán dicha indulgencia”.

46. Alena Robin, Las capillas del Via Crucis de la Ciudad de México. Arte, patrocinio y sacralización del espacio (México: Universidad Nacional Autónoma de México-Instituto de Investigaciones Estéticas, 20I4), I77. 
se habría de exponer, y después la reservaba en un "depósito". El mismo sacerdote debía "manifestar y depositar al Divino Sacramento". ${ }^{47}$ En el último día de la festividad "se dice otra misa rezada para consumir la forma que se expuso [durante los tres días]". ${ }^{8}$

El Jubileo Circular también se llevaba a cabo en Puebla de los Ángeles, aunque no he hallado información sobre cuándo comenzó a celebrarse. Además de las Cuarenta Horas, la hostia consagrada también se exponía el día de la Ascensión y el domingo infraoctavo después de Corpus Christi. ${ }^{49}$

Vale la pena preguntarse sobre cómo se develaba la hostia consagrada. Para responder a esa interrogante usaré un interesante manual impreso en la capital del virreinato casi al mediar el siglo xviII, en el que se explica la ceremonia que se debería seguir para manifestarla. El libro se intitula Manual arreglado al Ritual Romano, decretos de la Sagrada Congregación de Ritos, y Privilegios Apostólicos, según el estilo del Orden Seráfico; especial para el uso reformado de los Religiosos Franciscos Descalzos de la más estrecha observancia Regular de la Mexicana Provincia de San Diego, escrito por fray Pedro de Alcántara Fernández e impreso en 1748 . De acuerdo con la portada, su autor era "Mexicano, humilde hijo de la misma provincia".

El capítulo III de la segunda parte está dedicado a diferentes ceremonias relacionadas con la Eucaristía, y ahí se describe el "modo de descubrir y encerrar al Santísimo Sacramento". 50 El autor indica que se debía usar una "cortina" para mantener velado el Cuerpo de Cristo antes de manifestarlo.

De acuerdo con el Manual, el "hermano sacristán" tenía que cumplir con tareas específicas para que el Santísimo Sacramento fuera manifestado: colocar la hostia consagrada en la custodia "muy de mañana [...] en el tabernáculo donde se ha de descubrir", y cubrirla "con su cortina, de manera que a su tiempo pueda correrse y se descubra el Sacramento, sin embarazo". ${ }^{51}$ De igual manera, poner "dos velas encendidas en el altar, porque estando el Santísimo sólo

47. Robin, Las capillas, 178 .

48. Citado por Robin, Las capillas, 178 .

49. Esas noticias fueron tomadas del Manual citado en la nota 50.

50. Pedro de Alcántara Fernández, Manual arreglado al Ritual Romano, Decretos de la Sagrada Congregación de Ritos, y Privilegios Apostólicos, según el estilo del Orden Seráfico; especial para el uso reformado de los Religiosos Franciscos Descalzos de la más estrecha observancia Regular de la Mexicana Provincia de San Diego (México: Imprenta del Nuevo Rezado de Doña María de Rivera, en el Empedradillo, I748), 7I-87.

5I. Alcántara Fernández, Manual arreglado al Ritual Romano, $7 \mathrm{I}$. 
con la cortina, debe, fuera de la lámpara, tener dos luces".52 Pedro de Alcántara Fernández advierte que el hermano sacristán no debería esperar a "hacer esto ya que es hora de la Función, o que la Iglesia esté llena de gente, que es poca cordura, y no decencia". 53

De acuerdo con el autor, para manifestar a la Eucaristía debe celebrarse una procesión dentro del templo. La comunidad de frailes debe reunirse en la antesacristía, y "el religioso que ha de descubrir" debe revestirse con "amito, alba, estola, y capa blanca”. ${ }^{54}$ Ya que la comunidad estaba lista, se entraba al templo "por la puerta de gracias, o por la del presbiterio". $55 \mathrm{El}$ ingreso era en el siguiente orden: "los acólitos con los ciriales encendidos, el turíbulo con el incensario con lumbre (sin echar antes incienso, que no le toca) la comunidad irá saliendo detrás de los dichos, en orden, y último el preste", quien incensaba al Santísimo Sacramento. ${ }^{56}$ Al llegar al presbiterio, el sacerdote que iba revestido "echará tres veces incienso en el Incensario", e inmediatamente después "puesto de rodillas, tomará el incensario, y en empezando a levantar el velo o cortina inclinando profundamente la cabeza, y volviéndola a levantar, incensará al Santísimo tres veces todas derechas, y hechas, de modo, que sean en el tiempo que se gastare en descubrir, y a la última en la misma suerte que en la primera inclinará la cabeza". ${ }^{57}$ Además, los cantores debían entonar el Tantum ergo, un canto eucarístico.

Pedro de Alcántara Fernández advierte, además, que el fraile que fungía como sacristán debía ser quien descorriera las cortinas para manifestar a la Eucaristía: "El hermano sacristán, suponiendo, que deber ser sacerdote, luego que el preste se arrodilla [...] irá corriendo la cortina para descubrir el Sacramento, ni muy de prisa, ni muy despacio, sino con decencia y gravedad", y aconsejaba: "Si él no pudiere hacerlo lo encomendará a otro Sacerdote, no a cualquier mozo"..$^{8}$

En el Manual se describe, también, la forma en la que se debía celebrar la exposición eucarística durante el Jubileo Circular. Como se ha visto, antes de

52. Alcántara Fernández, Manual arreglado al Ritual Romano, 7I.

53. Alcántara Fernández, Manual arreglado al Ritual Romano, 7I.

54. Alcántara Fernández, Manual arreglado al Ritual Romano, 72.

55. Alcántara Fernández, Manual arreglado al Ritual Romano, 72. Ignoro en qué parte de los templos se ubicaba la "puerta de gracias".

56. Alcántara Fernández, Manual arreglado al Ritual Romano, 72.

57. Alcántara Fernández, Manual arreglado al Ritual Romano, 72.

58. Alcántara Fernández, Manual arreglado al Ritual Romano, 73. 
I785 en la capital del virreinato las Cuarenta Horas se distribuían en tres días. En el Manual se señala que la hostia consagrada "se debe descubrir el primero y segundo día, a las cinco en punto de la mañana, y depositar en punto de las seis y media de la tarde, y el día tercero se descubre a las cinco en punto, y en punto de las siete de la tarde se deposita". ${ }^{59}$ Los dos primeros días del Jubileo Circular, cuando el anochecer se aproximaba, el Cuerpo de Cristo se ocultaba con las cortinas, con la misma solemnidad con la que había sido manifestado, y para ello era necesario que de nuevo fuera incensado por el preste. En el último día de la festividad, inmediatamente después de que se habían corrido los velos, el sacerdote bendecía a los fieles con el Santísimo Sacramento. En el Manual se dice que la bendición se debía efectuar con otra hostia consagrada, la cual estaba reservada en el "depósito" para ese fin. Con ese acto, finalizaban las cuarenta horas de exposición eucarística. ${ }^{60}$

En muchos retablos mayores del periodo virreinal con seguridad se utilizaron cortinas para manifestar a la Eucaristía. Por fortuna existen diferentes ejemplos — relieves arquitectónicos o tallados en madera, pinturas, estampas, etc.- que dan testimonio de esa costumbre perdida. En esas obras se observan cortinajes enmarcando el ostensorio que aloja a la Sagrada Forma. Se podría aducir que esas cortinas aparecen sólo como mera ornamentación. Sin embargo, creo que esos ejemplos son claras representaciones de la exposición eucarística.

59. Alcántara Fernández, Manual arreglado al Ritual Romano, 72.

6o. Por fortuna subsiste una pintura del siglo Xvin en la que se representó la bendición con el Santísimo Sacramento, la cual se conserva en el templo conventual de Tecamachalco, Puebla. La escena fue identificada por Jaime Morera, quien señaló que en ella el celebrante "viste de amito, alba, estola cruzada (por lo cual se sabe que es un presbítero y no un obispo) y capa pluvial”, quien a su vez es asistido por un diácono y un subdiácono que "llevan amito, alba, estola y dalmática". La escena es descrita por el citado autor de la siguiente forma: "El momento de la ceremonia que se ve en la pintura es aquél en que el diácono acaba de entregar el ostensorio al celebrante, quien lo ha tomado con el humeral, de manera que tanto sus manos como el pie del ostensorio quedan cubiertos. A continuación, se vuelve al pueblo para dar la bendición elevando primeramente el ostensorio desde el pecho hasta los ojos; lo lleva después hasta debajo del pecho; lo vuelve a levantar y mueve a la izquierda, después a la derecha, y otra vez en medio e inmediatamente a la izquierda, para devolverlo finalmente al diácono. Durante este solemnísimo momento, el celebrante debe hacer despacio todos los movimientos y girar su cuerpo sin mover los pies", Jaime Morera, "El cofre del tesoro de la iglesia: las indulgencias", en Imágenes de los naturales en el arte de la Nueva España, siglos XVI al XVIII (México: Fomento Cultural Banamex/Universidad Nacional Autónoma de México-Instituto de Investigaciones Estéticas-Dirección General de Asuntos del Personal Académico, 2005), 447. 


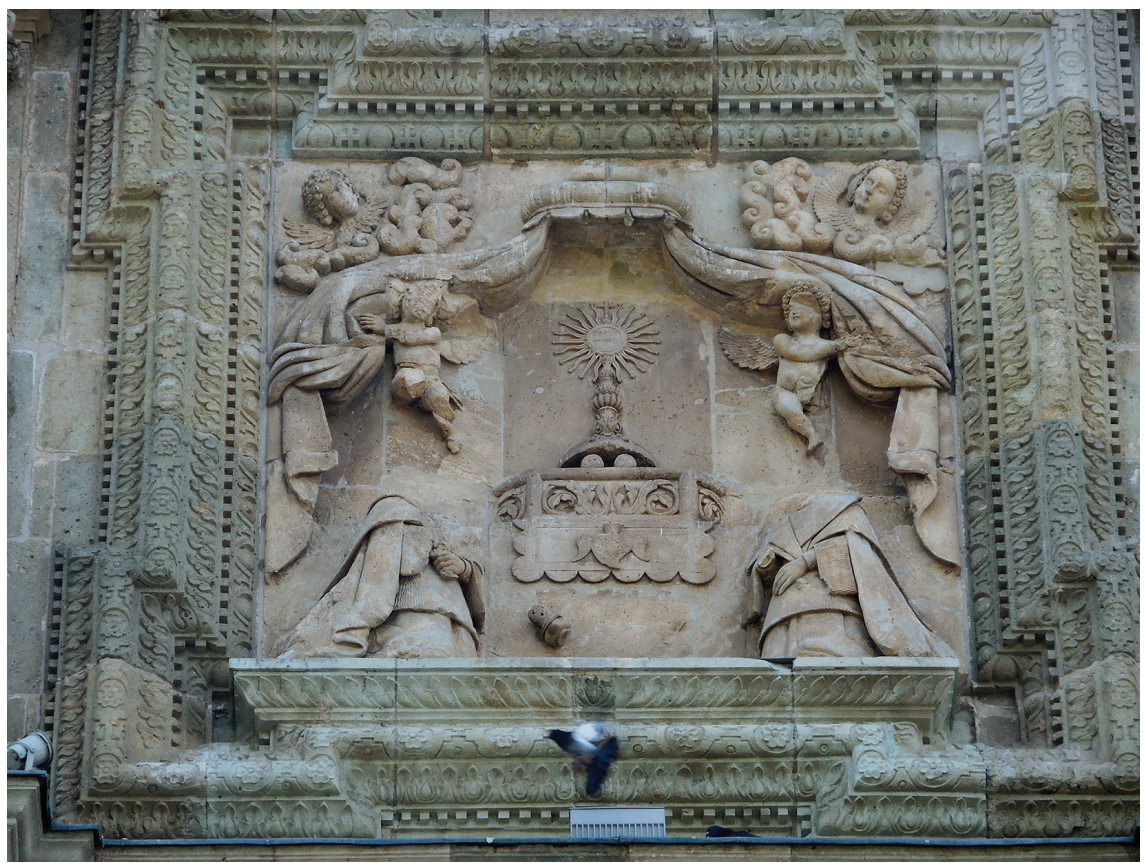

5. Relieve superior de la portada principal de la catedral de Oaxaca, mediados del siglo XviII. Foto: Guillermo Arce. Secretaría de Cultura.-INAH. Méx.- "Reproducción autorizada por el Instituto Nacional de Antropología e Historia”.

Hay desde obras muy sencillas hasta representaciones mucho más complejas. En este artículo sólo me referiré al relieve que se haya en la parte alta de la calle central de la portada principal de la catedral de Oaxaca (fig. 5), en el que se observa cómo "bajo cortinaje o dosel que extienden dos angelillos niños irradia la Eucarística Custodia [...] Dos clérigos que han perdido literalmente la cabeza, inciensan el culminante Misterio Eucarístico". ${ }^{61}$ La presencia de los sacerdotes turiferarios invita a recordar que el Cuerpo de Cristo era incensado mientras se descorrían las cortinas, tal y como se lee en el Manual de fray Pedro de Alcántara Fernández.

Una característica particular del relieve catedralicio oaxaqueño es la presencia de los ángeles que descorren el cortinaje para manifestar a la Eucaristía.

6I. Manuel González Galván, "El rostro oculto de la catedral de Oaxaca", Anales del Instituto de Investigaciones Estéticas XV, núm. 58 (1987): 94-95. 
6. Miguel Cabrera (atribuido), Nuestra Señora de Guadalupe con fray Juan de Zumárraga y Juan

Diego, mediados del siglo XviII, óleo sobre lámina de cobre, Museo Nacional de Arte. Foto: Guillermo

Arce. Reproducción autorizada por el Instituto Nacional de Bellas Artes y Literatura, 2019.

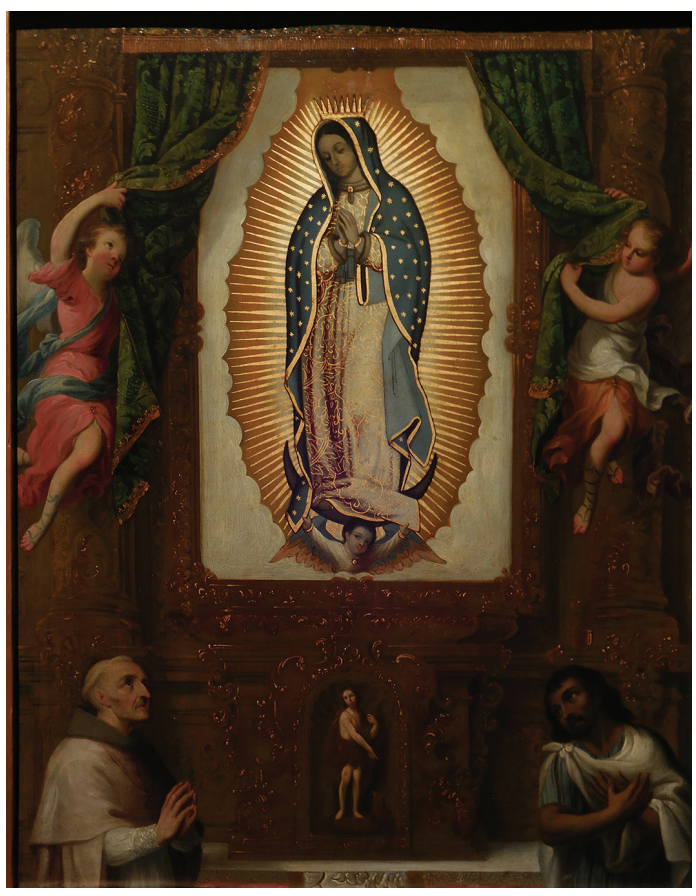

$\mathrm{Al}$ respecto, debe señalarse que los seres celestes que ejecutan esta acción no son exclusivos de las representaciones de la exposición eucarística. Los velos descorridos por ángeles son característicos de cuadros que retratan imágenes sagradas. Baste aquí mencionar una pintura sobre lámina de cobre atribuida a Miguel Cabrera, la cual forma parte del acervo del Museo Nacional de Arte (fig. 6). La imagen central de ese cuadro es la Virgen del Tepeyac, ante la cual se hallan fray Juan de Zumárraga y Juan Diego, los principales testigos del milagro guadalupano. En palabras de Jaime Cuadriello, en el cuadro se observa cómo "dos ángeles volanderos descorren un lujoso cortinaje de brocado verde ribeteado en oro a la altura del dosel". ${ }^{62}$ El citado historiador del arte ha señalado que esa pintura y otros testimonios escritos revelan que la tilma guadalupana se hallaba oculta la mayor parte del año, y que sólo podía ser vista "en las

62. Jaime Cuadriello, "El Obrador Trinitario o María de Guadalupe creada en idea, imagen y materia", en El divino pintor: la creación de María de Guadalupe en el taller celestial (México: Museo de la Basílica de Guadalupe, 200I), 90. 
solemnidades y fiestas mayores". ${ }^{63}$ En otras palabras, la Virgen de Guadalupe recibía un culto semejante al que se tributaba a la Eucaristía.

Entre los testimonios escritos sobresale el de Francisco de Florencia, en la segunda mitad del siglo XVII, quien al describir el retablo mayor del santuario mariano señaló que el ayate se hallaba en un "tabernáculo de plata maciza", en donde la imagen mariana por lo general estaba oculta:

En éste está colocada la Santa Imagen debajo de puerta, y llave: y es la puerta de dos bellas lunas de Cristal, tan grandes, que cogen la Imagen de pies a cabeza: de más de dos ricos velos o cortinas, con que está retirada a la vista cuando no se dice misa en el altar mayor, o cuando no hay personas de respeto, que para velar ante Ella piden se corran, y entonces se encienden las luces del altar para mayor adorno y reverencia. ${ }^{64}$

La costumbre de mantener oculta a la tilma de Juan Diego pervivió por lo menos hasta las postrimerías de la época virreinal, tal y como lo prueban las indagaciones de Jaime Cuadriello. En 1778 se discutió en el cabildo del santuario mariano "un proyecto para construir un pequeño camarín con un torno abatible que expusiese alternadamente una réplica 'a la espalda', cuando no estuviese 'en adoración' o tuviera que guardarse el Sagrado Original”. ${ }^{65}$ En I794, en una sesión del mismo cabildo "se tuvo que reprender al padre sacristán por permitir que manos no consagradas, como las de la servidumbre seglar que asistía a la sacristía, descorriesen las misteriosas cortinas" ${ }^{66}$ Por otro lado, un inventario de I8I3 del ajuar litúrgico del santuario mariano señala que una de las cortinas que se empleaban para mantener oculta a la Virgen "estaba bordada con una imagen guadalupana, sustituta de la original" ${ }^{67}$

La imagen de la Virgen de Guadalupe no fue la única en el virreinato que estaba velada con cortinajes. ${ }^{68}$ En realidad, otras efigies de gran devo-

63. Cuadriello, "El Obrador Trinitario", 84.

64. Francisco de Florencia, La estrella de el norte de México, aparecida el rayar el día de la luz evangélica en este Nuevo Mundo en la cumbre de el cerro de Tepeyacac orilla del mar tezcucano, a un natural recién convertido, pintada tres dias después milagrosamente en su tilma o capa de lienzo, delante del obispo y de su familia en su casa obispal (México: Dońa María de Benavides, viuda de Juan de Ribera, I688), 2I-22.

65. Cuadriello, "El Obrador Trinitario", 87.

66. Cuadriello, "El Obrador Trinitario", 87-88.

67. Cuadriello, "El Obrador Trinitario", 88.

68. Muchos retablos virreinales construidos en el transcurso del siglo XVIII tienen ángeles que simulan descorrer cortinajes para develar a las imágenes sagradas. Para Sergi Doménech García, tal 
ción también se mantenían ocultas a los ojos de los fieles la mayor parte del tiempo. ${ }^{69}$

\section{El manifestador del retablo mayor de Tepotzotlán: la Virgen de Guadalupe, los siete principes y la preeminencia del arcángel san Miguel}

En diferentes casos no se utilizaron cortinas para manifestar a la Eucaristía, sino que se fabricaron artefactos de mayor complejidad, ya sea por su mecanismo o bien por su iconografía. Por ejemplo, en Tutuaca, Chihuahua, se conserva un manifestador de madera, que de acuerdo con Clara Bargellini se construyó a finales del siglo xviII. ${ }^{70}$ En la parte frontal de ese aparato hay dos secciones en las que está pintada una custodia con la hostia consagrada (fig. 7). Las dos "portezuelas" se separaban cuando se manifestaba al Santísimo Sacramento, y para ello era necesario hacer girar dos palancas de madera que se ubicaban a los lados, mediante las cuales se accionaba un sistema de engranes de madera. Seguramente, en muchos retablos virreinales con manifestador hubo representaciones de la Eucaristía en el ostensorio que mantenían oculto el Cuerpo de Cristo antes de manifestarlo.

Por esa razón, tal vez cause extrañeza que en el retablo mayor de Tepotzotlán fuera una Virgen de Guadalupe la que mantuviera oculto el Cuerpo de Cristo hasta que fuera manifestado. Sin embargo, no se trata de un caso excepcional. $\mathrm{Al}$ examinar la historiografía sobre ese retablo se constata que su manifestador debía ser "de la hechura del que está ejecutado en la casa o recogimiento de las

simulación "podría verse como un trasunto de la forma en la que originalmente sería presentada la imagen en los actos litúrgicos, o incluso podía formar parte de un juego teatral, tan del gusto barroco, en el que, como si una vez descorrido el telón real, para asombro de los devotos allí congregados, se quisiera mostrar un portento por el cual unos ángeles habían sido los verdaderos ejecutores del acto", Sergi Doménech García, "Función y discurso de la imagen de devoción en Nueva España. Los 'verdaderos retratos' marianos como imágenes de sustitución afectiva”, Tiempos de América. Revista de Historia, Cultura y Territorio, núm. I8 (20II): 89.

69. Para aproximarse a casos de imágenes sagradas en el virreinato de Nueva Granada que habitualmente permanecían veladas por cortinajes es necesaria la lectura del reciente artículo de Olga Isabel Acosta Luna, "Ver para creer. La develación de la imagen milagrosa en el Nuevo Reino de Granada”, en Visiones renovadas del barroco iberoamericano, eds. María del Pilar López y Fernando Quiles (Sevilla: Universidad Pablo de Olavide/Universidad Nacional de Colombia/ Alcaldía Mayor de Bógota D. C./Universidad de los Andes, 2016), 60-73.

70. Comunicación personal. Agradezco a la doctora Bargellini la noticia de ese manifestador. 
Vizcaínas". Gracias a esa noticia es posible inferir que en el manifestador del retablo mayor de Vizcaínas también hubo una Guadalupana que mantenía oculta a la Eucaristía. Además de los casos de Vizcaínas y Tepotzotlán, existieron por lo menos dos retablos más con figuras de la Virgen de Guadalupe en el manifestador.

Tan sólo unos años antes de la fabricación de ambas obras, Felipe de Ureña y su yerno, Juan García de Castañeda, fueron contratados en 1747 para fabricar tres retablos para el templo del colegio jesuita de Zacatecas, entre ellos el mayor. ${ }^{71}$ Por desgracia, ese retablo ya no existe, pero es posible imaginar cómo fue gracias a una descripción publicada en la Breve descripción de la fábrica y adornos del templo de la Compañia de Jesús de Zacatecas, en 1750 . De acuerdo con ella, ese retablo fue un obra de "superior fantasía", conformado por un cuerpo dividido en tres calles delimitadas por "cuatro bizarros estípites" ${ }^{72}$ En el nicho de la calle central había una "bellísima imagen de la Concepción, titular y patrona del templo", ${ }^{73} \mathrm{y}$ en el remate se observaban "dos de las personas de la TRINIDAD AUGUSTÍ́sIMA, figurada la una en la amabilidad de una paloma, y la otra en un anciano venerable, revestido de majestuoso pluvial y coronado de insignia de divinidad". ${ }^{74}$ Además, ese conjunto artístico tenía "doce admirables simulacros [los doce apóstoles] y nueve medallones de medio relieve"..$^{75}$ La parte que más me interesa de ese retablo es evidentemente su manifestador, que se describe así:

Debajo del nicho principal [el de la Inmaculada Concepción], a distancia de una vara, queda vaciado otro grande nicho, en que, como distinto, aunque pequeño altar, se embebe, sin ajustar del todo, el tabernáculo o sagrario, cuya peregrina fábrica remeda con viveza la de todo el retablo, cuanto permiten sus tamaños. De los tres pequeńos nichos de que se compone el de en medio, que es el mayor, guarnecido de cristales, sirve para exponer a la pública adoración el Divinísimo Sacramento. Lo que se ejecuta, dando vuelta a un curiosísimo torno, que voltea dentro de los

7I. Fátima Halcón, Felipe de Ureña. La difusión del estipite en Nueva España (Sevilla: Universidad de Sevilla, 20I2), 86-88 y 90.

72. Breve descripción de la fábrica y adornos del templo de la Compañía de Jesús de Zacatecas, con una sucinta relación de las fiestas con que se solemnizó su dedicación (México: Viuda de don Joseph Bernardo de Hogal, I750), 8.

73. Breve descripción, 9.

74. Breve descripción, 8.

75. Breve descripción, 8. 
7. Anónimo novohispano, Manifestador, finales del siglo xvin, Tutuaca, Chihuahua.

Foto: Libertad Villarreal. Secretaría de Cultura.-INAH. Méx.- "Reproducción autorizada por el Instituto Nacional de Antropología e Historia”.

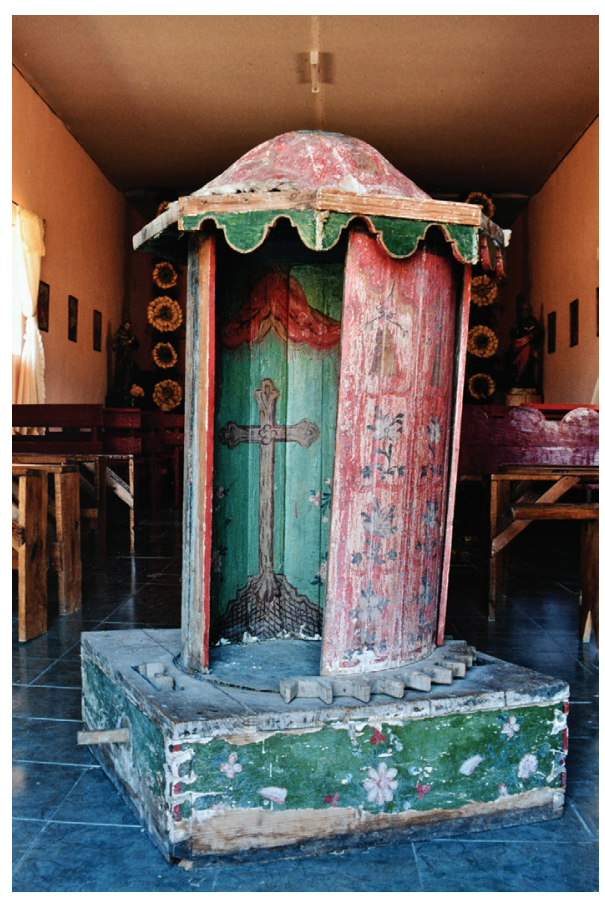

cristales, de los que está también guarnecido el Torno por la parte de dentro, y por la de fuera, de una rica de lámina de plata, en que está grabada una Imagen de GUADALUPE, y es la que por vidriera se descubre el tiempo, que se mantiene encubierto el adorable Sacramento. ${ }^{76}$

De acuerdo con la descripción transcrita, el "tabernáculo o sagrario" tenía "tres pequeños nichos", de los cuales el central era usado para exponer la Eucaristía. En el retablo zacatecano, como en Tepotzotlán, una Virgen de Guadalupe mantenía oculto el Santísimo Sacramento, aunque no se trataba de una obra pictórica, sino de un relieve de plata.

Un retablo que también tuvo una Guadalupana en el manifestador se hallaba en el templo del convento de Santa Bárbara, en Puebla de los Ángeles. El retablo fue descrito por Mariano Fernández de Echeverría y Veytia así: 
El altar mayor está adornado de un retablo dorado al gusto antiguo, que sube hasta la bóveda, en cuyo centro está colocada la imagen de bulto de la gloriosa Virgen Santa Bárbara y en el mismo año de [17]76 cuando se hizo la obra del presbiterio, con lo que éste bajó, dio campo para sobreponer en el cuerpo inferior del retablo un bello tabernáculo para colocar al Augustísimo Sacramento, de muy buena talla y dorado, con sus cristales por la fachada y los lados, sirviéndole de cortina una imagen de Nuestra Señora de Guadalupe de México, que se recoge hacia arriba por la parte interior del trono cuando se manifiesta el Santísimo, y cuando no, queda la santa imagen expuesta al culto, resguardada de la misma vidriera. ${ }^{77}$

El autor poblano aclara que, originalmente, el piso del presbiterio "estaba elevado sobre ocho gradas, que no corrían por todo su largo y sólo formaban la subida en medio de él, hasta el año de 1776 que se bajó, dejándole sólo tres escalones, que corresponde uno y otro muro, con que quedó más amplio y hermoso".${ }^{78} \mathrm{La}$ modificación permitió integrar al retablo mayor, que era "al gusto antiguo" un nuevo "tabernáculo", es decir, un manifestador.79

Vale la pena preguntarse por qué en esos casos se escogió una imagen guadalupana para un lugar destinado a la presencia de la Eucaristía. Al respecto, hay que decir que en diferentes ceremonias de la liturgia católica se evocan diferentes episodios bíblicos, sobre todo del Nuevo Testamento. En la misa, durante la consagración del pan y el vino se rememora la Última Cena. ¿Qué episodio de la Biblia se recuerda con la exposición del Santísimo Sacramento? Tal vez, el pasaje que más se acerca a lo que los fieles veían cuando se manifestaba la hostia consagrada es la resurrección. El Evangelio de San Mateo dice que cuando Jesús resucitó, un ángel quitó la piedra que tapaba el sepulcro. ${ }^{80}$ Algo semejante ocurría durante la exposición, cuando se descorrían los cortinajes para mostrar a Cristo sacramentado. No es gratuito que en algunas representaciones de la exposición eucarística - como el relieve de la portada oaxaqueña- sean seres alados los que descorren las cortinas.

77. Mariano Fernández de Echeverría y Veytia, Historia de la fundación de la Puebla de los Ángeles en la Nueva España, su descripción y presente estado, ed. Efraín Castro Morales, lib. II (Puebla: Ediciones Altiplano, 1963), 306.

78. Fernández de Echeverría y Veytia, Historia de la fundación, 305-306.

79. El adjetivo "antiguo" indica que pudo haber sido un retablo del siglo XvII o principios del XviII, y posiblemente tenía columnas revestidas o salomónicas.

80. San Mateo, 28: 2-3. 
Sin embargo, la resurrección no fue el único episodio que pudo haber sido relacionado con la exposición de la Eucaristía. En los casos de Zacatecas, Vizcaínas, Tepotzotlán y Puebla, el episodio que es posible relacionar con esos retablos está en el Apocalipsis. Como es sabido, la iconografía de la Virgen de Guadalupe está inspirada precisamente en una de las visiones del apóstol San Juan. En el capítulo I2 de ese libro profético se lee cómo el evangelista vio "un signo sorprendente" en los cielos: una mujer encinta, "vestida de sol, con la luna bajo sus pies", y ante ella un ser monstruoso, un dragón con siete cabezas y diez cuernos. El ser infernal estaba esperando a que la mujer diera a luz, para devorar a su hijo. Sin embargo, él fue llevado ante Dios y su trono, y el dragón fue combatido por el arcángel san Miguel. La tradición ha identificado a la Mujer Apocalíptica con la Virgen María.

Al parecer, con las Guadalupanas de los manifestadores de los retablos señalados se buscaba lograr una secuencia narrativa conformada por dos momentos. La primera parte se daba antes de la exposición, cuando el Cuerpo de Cristo se mantenía velado por una imagen de su madre. La figura de la Virgen de Guadalupe estimulaba a los fieles para que recordaran la visión de la Mujer Apocalíptica. Así como la Virgen tuvo en su vientre a Jesús durante nueve meses, así también la Guadalupana del manifestador lo mantenía encerrado y oculto los momentos previos a la exposición. La segunda parte de la narración ocurría cuando se manifestaba la hostia consagrada, cuando los fieles podían adorar a Cristo sacramentado.

La presencia de la Guadalupana del manifestador no fue mencionada en el contrato. Sin embargo, ya vimos que es una obra salida del pincel de Miguel Cabrera pues tiene el "ocho" en su túnica, que como ya se mencionó fue incorporado por aquel artista a las copias de la Virgen del Tepeyac. En contraparte, el contrato sí estipula la presencia de los "siete príncipes" en el "sagrario", es decir, de los siete arcángeles.

El retablo mayor de Tepotzotlán se distingue por la presencia de ángeles, de muy distintos tamańos. Al mirarlo es fácil reconocer la destacada presencia de seres alados en dicha obra, sobre todo a los lados de san Francisco Javier - a quien está dedicado el retablo-, la Inmaculada Concepción y los distintos santos que se hayan en él. Pero, al mirar el manifestador se advertirá la ausencia de ángeles a su alrededor (fig. 8). Sin embargo, una observación más cuidadosa permitirá entrever que seis de los "siete príncipes" mencionados en el contrato estaban flanqueando el "sagrario de torno", tres a la izquierda de la Guadalupana y tres en el lado opuesto. Desafortunadamente dichas figu- 
ras escultóricas han desaparecido y no he hallado noticias sobre cuál ha sido su destino.

En concreto, las evidencias que permiten considerar que a los lados del manifestador se hallaban seis arcángeles son seis pequeñas peanas. Específicamente, a los lados de la Virgen de Guadalupe hay dos pares de pilastras que tienen pequeñas peanas en la parte baja. Asimismo, entre esas pilastras hay dos peanas más, a mayor altura, apenas visibles.

Abajo del manifestador del retablo de Tepotzotlán se ubica el "depósito". Lamentablemente, esa parte ha sido muy modificada y ni siquiera conserva su puerta original. Arriba del manifestador hay una cornisa que, con suficiente claridad, separa un remate de ese cuerpo. En la parte central del remate hay roleos y hojas, y entre ellos se observa una cruz. Es necesario señalar que en algunas fotografías antiguas de esa parte del retablo se observan dos ángeles de aspecto infantil flanqueando la cruz. En la actualidad, esas tallas han desaparecido. Cabe aclarar que esas tallas no formaron parte del conjunto que representaba a las siete príncipes, y así lo evidencia tanto su fisonomía infantil como su atuendo.

Para continuar es oportuno explicar quiénes son los "siete príncipes". De ese grupo, los más conocidos son los arcángeles san Miguel, san Rafael y san Gabriel, quienes son mencionados en diferentes partes de la Biblia, ya sea en el Antiguo Testamento o en el Nuevo Testamento. El arcángel san Miguel, como ya vimos, es uno de los personajes del capítulo I2 del Apocalipsis. Asimismo, en el Antiguo Testamento, específicamente en Tobías, se relata cómo el arcángel Rafael, cuando se dio a conocer a Tobit y a su hijo les dijo: "Yo soy Rafael, uno de los siete ángeles que están siempre presentes y tienen entrada a la gloria del Señor" ${ }^{81}$ Cabe destacar que el libro de Tobías es uno de los pasajes de la Biblia en los que se habla de la existencia de siete arcángeles. Finalmente, san Gabriel es el arcángel que anunció a la Virgen María el nacimiento de Cristo, episodio narrado por san Lucas y que indudablemente es uno de los episodios más conocidos de ese Evangelio. Por el hecho de ser mencionados en la Biblia a esos tres arcángeles se les conoce como "canónicos".

Los cuatro arcángeles restantes, conocidos como Uriel, Sealtiel, Jehudiel y Barachiel, no son mencionados en ninguno de los libros que integran la Biblia. Sin embargo, sus nombres están en obras que han sido atribuidas a la autoría de algún autor prestigiado para la fe cristiana. Por ejemplo, Uriel aparece

8I. Tobit, I2:15 (las cursivas son mías). 
8. Miguel Cabrera e Higinio de Chávez, retablo de san Francisco Javier (detalle), contratado el 7 de diciembre de $1753 \mathrm{y}$ posiblemente estrenado el 3 de diciembre de 1754, Museo Nacional del Virreinato, Tepotzotlán. Foto: Pedro López Agustín.

Secretaría de Cultura.-InAH. Méx."Reproducción autorizada por el Instituto Nacional de Antropología e Historia”.

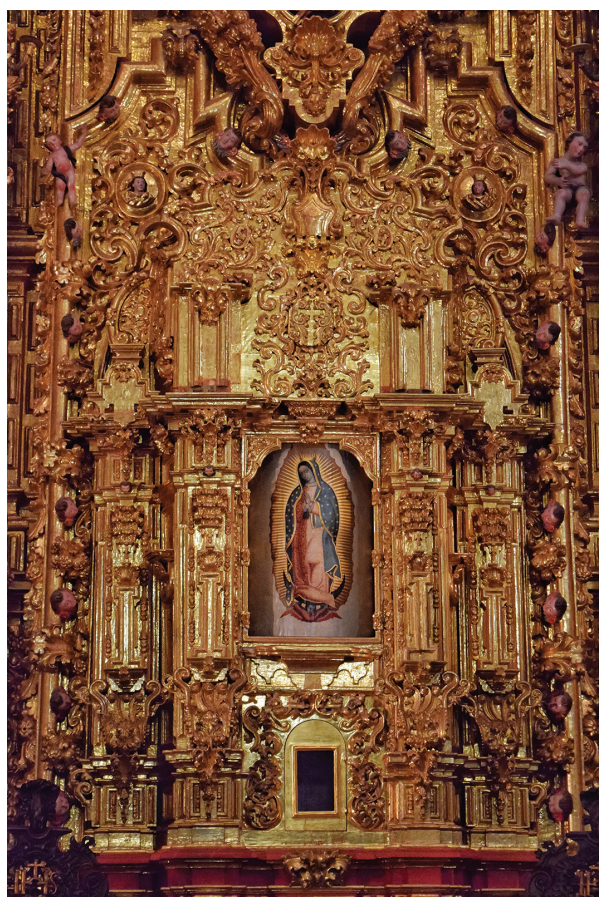

en los libros III y IV de Esdras, los cuales no forman parte del canon bíblico. En palabras de Sergi Doménech García, "con 'apócrifos' se indica que el culto se establece en razón de la tradición, de algún texto atribuido a autor sagrado, pero que, sin embargo, no está incluido en el canon de la Biblia". ${ }^{82}$

82. Sergi Doménech García, "La formación de la imagen de los siete príncipes. Descripción diacrónica, fuentes y hermenéutica”, en Imago. Revista de emblemática y cultura visual, núm. I (2009): I20. A pesar de que los nombres de Uriel, Sealtiel, Jehudiel y Barachiel no están en el Antiguo o el Nuevo Testamento, ello no impidió que su culto se desarrollara a partir de la segunda mitad del siglo xvi. Sin embargo, se trata de un culto controvertido. Así pues, como lo ha expresado Escardiel González: "Los Siete Príncipes de los Ángeles fueron, en materia de heterodoxia, un caso sensiblemente ambiguo, ya que su número era perfectamente canónico [puesto que en la Biblia se habla de la existencia de siete arcángeles], pero sus nombres sólo lo eran en tres casos, no en el resto. La synaxis, por tanto, quedaba configurada por cuatro nombres apócrifos: Uriel, Jehudiel, Sealtiel y Barachiel, que se unía a la tríada canónica de Miguel, Gabriel y Rafael; generando una ambigüedad, utilizada al antojo de partidarios o detractores", Escardiel González Estévez, "La controversia en torno a los nombres apócrifos del septenario angélico y su incidencia sobre la iconografía", en Arte barroco y vida cotidiana en el mundo hispánico. Entre lo 
A pesar de los antecedentes literarios apenas mencionados, el culto a los siete príncipes no se desarrolló sino hasta I516. En ese año, en Palermo, fue hallado un antiguo mural - ahora desaparecido - en el que estaban plasmadas las figuras de aquellos siete seres celestes. El hallazgo se consideró un hecho prodigioso, e inclusive el mural se convirtió en un "modelo sacro sobrenatural" para la realización de obras posteriores. ${ }^{83}$

Asimismo, no es posible explicar cómo se desarrolló el culto a los siete arcángeles sin la influencia de la imprenta. Ciertamente, no es posible que en este trabajo me refiera a todas esas obras. ${ }^{84}$ Sin embargo, para los propósitos del presente artículo quisiera llamar la atención sobre dos distintos autores que militaron en la Compañía de Jesús: Rafael de Bonafé, quien escribió Títulos de excelencia y oficios de piedad del arcángel S. Rafael, uno de los siete asistentes de Dios, presidente de la salud y protector de la casa y familia de Tobias -escrita en Manila e impresa en Madrid en $1659^{85}$ - y el murciano Andrés Serrano, quien es autor de Feliz memoria de los siete príncipes de los ángeles asistentes al trono de Dios y estímulo a su utilisima devoción. Miguel, Gabriel, Rafael, Uriel, Sealtiel, Jehudiel, Barachiel —escrita en Filipinas e impresa en I699 en la Ciudad de México ${ }^{86}$ - y Los siete príncipes de los ángeles, validos del rey del cielo. Misioneros y protectores de la tierra, con la práctica de su devoción -impresa en Bruselas en 1707. ${ }^{87}$ Ambos autores jesuitas se refieren de uno u otro modo a

sacro y lo profano, coord. Paula Revenga Domínguez (Zamora: El Colegio de Michoacán/UcoPress. Editorial Universidad de Córdoba, 2017), I59-160.

83. Sergi Doménech García, "Imagen y devoción de los siete príncipes angélicos en Nueva España y la construcción de su patrocinio sobre la 'evangelización", Ars Longa, núm. 23 (2014): 154-I55.

84. Para ello remito al trabajo de Doménech García, "Imagen y devoción”, I5I-I72, quien ha valorado las distintas obras que influyeron en el culto y la iconografía de los siete príncipes en el México virreinal, impresas ya sea en la Nueva España o fuera del virreinato.

85. Rafael de Bonafé, Titulos de excelencia y oficios de piedad del arcángel S. Rafael, uno de los siete asistentes de Dios, presidente de la salud y protector de la casa y familia de Tobias (Madrid: Don Francisco Nieto y Salcedo, 1659). Se trata de la primera obra dedicada a los siete arcángeles que fue impresa fuera de Europa. Sin bien "está centrada en la figura de San Rafael, es en realidad un tratado sobre estos seres angélicos”, Doménech García, Imagen y devoción, I6I.

86. Andrés Serrano, Feliz memoria de los siete principes de los ángeles asistentes al trono de Dios y estimulo a su utilísima devoción. Miguel, Gabriel, Rafael, Uriel, Sealtiel, Jehudiel, Barachiel (México: Juan Joseph Guillena Carrascoso, I699).

87. Andrés Serrano, Los siete príncipes de los ángeles, validos del rey del cielo. Misioneros y protectores de la tierra, con la práctica de su devoción (Bruselas: Francisco Oppens, 1707). Cabe señalar que la segunda obra de Serrano es una versión corregida y ampliada de lo que había sido publicada ocho ańos antes en la capital de la Nueva España, lo cual ha sido señalado por autores como 
dos distintos tópicos que será posible relacionar con el manifestador del retablo mayor de Tepotzotlán: la preeminencia del san Miguel y la relación de los siete príncipes con la madre de Cristo.

Rafael de Bonafé escribió que san Miguel es el primero de los siete príncipes, seguido por Gabriel y Rafael, y lo expresó con claridad en las primeras páginas de su obra: "El más piadoso sentir de los sagrados doctores da este lugar al glorioso Arcángel san Miguel, a quien la Iglesia reconoce por primado de los celestiales ejércitos, y prepósito, o prefecto del paraíso". ${ }^{88}$

Por otro lado, Andrés Serrano se refiere a la relación de los siete príncipes con la Virgen María, afirmando que:

haber sido estos siete [espíritus] los que con más demostraciones de fineza y amor la cortejaron y sirvieron desde el primer instante de su concepción inmaculada hasta que subió triunfante al paraíso [...] Todos ellos en compañía de su Capitán general Miguel resistieron y llenaron de confusión al Dragón, y para que la culpa que intentaba introducir en la alma de MARÍA, no llegase a imprimir su mancha ni a tender el manto de sus sombras en esta hija de la felicidad, hicieron de las entrańas de Santa Ana un cielo de cristal, por donde se espaciase el Sol de Dios sobre el horizonte de la gracia. ${ }^{89}$

Así pues — como ya ha sido destacado por Sergi Doménech García- son numerosas los retablos o portadas fabricados en el transcurso del siglo XviII en las que la Virgen María está rodeada por los siete arcángeles. En aquellas obras de arquitectura o talla en madera, además, la primacía de san Miguel sobre los seis arcángeles restantes se expresó casi siempre colocándolo en el centro, arriba de la Virgen. Así se observa por ejemplo, en el retablo dedicado a la Virgen del Pilar de la parroquia de Santa Prisca en Taxco y en la portada del santuario mariano de Ocotlán, Tlaxcala, en donde los arcángeles "aparecen dispuestos en nichos, capitaneados por San Miguel". ${ }^{\circ}$

Sin embargo, en el retablo de Tepotzotlán no hay una peana arriba de la

Escardiel González Estévez, "De fervor regio a piedad virreinal. Culto e iconografía de los siete arcángeles”, SÉMATA. Ciencias Sociais e Humanidades, núm. 24 (2012): I24 y Doménech García, "Imagen y devoción", I56-I55.

88. Bonafé, Títulos de excelencia, 3. Cabe señalar que Sergi Doménech García destacó la importancia de esa cita de la obra de Bonafé y su probable influjo en la plástica novohispana: Doménech García, "La formación”, I2I.

89. Serrano, Feliz memoria, 94.

90. Doménech García, "Imagen y devoción”,I55. 
Virgen de Guadalupe. Como ya se destacó, sólo hay seis peanas a los lados de aquella imagen mariana, seis a la izquierda y seis a la derecha. Por tal razón no resulta claro en dónde se ubicaba la figura del arcángel san Miguel. En los párrafos que siguen quiero señalar una posibilidad aún no señalada en la historiografía del retablo mayor de Tepotzotlán: san Miguel es el único de los siete príncipes que ha sobrevivido, mas no es una escultura sino que se trata del ángel infantil que sostiene a la Virgen de Guadalupe pintada por Miguel Cabrera. Durante la época virreinal —específicamente durante los siglos XVII y XVIIIhubo quienes consideraron que el ángel que está sosteniendo a la Virgen del Tepeyac es el arcángel san Miguel.

Diferentes autores del periodo tomaron la pluma para especular sobre la identidad del ser alado, pues en palabras de Rosario Inés Granados Salinas:

Para los ojos terrenales, entonces, lo que se hacía necesario era dar respuesta a la identidad del ángel que se veía en el mismo lienzo a los pies de la imagen. No sólo era ocio el que los movía, sino la gana de saber quién, de entre todos los mensajeros divinos, servía de atlante a santa María de Guadalupe y recibía con ello, parte de las oraciones que se le dedicaban. ${ }^{91}$

Hubo quienes consideraron que se trataba de uno de los siete príncipes. Unos creyeron que se trataba de san Gabriel, en tanto otros afirmaron que era san Miguel. Como se verá, con ese segundo grupo estuvo relacionado el pintor Miguel Cabrera. Analizaré ambas opiniones. En el siglo XvII, Francisco de Florencia en La estrella del norte transcribió la opinión de un "erudito y piadoso jesuita de esta provincia”. ${ }^{92}$ Para ese jesuita, el ángel que sostiene a la Guadalupana es el que anunció a la Virgen que sería madre del mesías: "Sólo México se alza por privilegio especial de esta Sagrada Imagen con el blasón singular Non fecit taliter omni Nationi, y sólo el arcángel san Gabriel se levanta, digámoslo

91. Rosario Inés Granados Salinas, “Una travesía con olor a yaubtli: el descenso de la imagen al Tepeyac", en El divino pintor: la creación de María de Guadalupe en el taller celestial (México: Museo de la Basílica de Guadalupe, 200I), 208. Una primera aproximación a autores de la época virreinal que identificaron al ángel que sostiene a la Guadalupana con san Miguel fue emprendida por Jaime Cuadriello, "Triunfo y fama del Miguel Ángel americano: el nombre de Miguel Cabrera”, en XVII Coloquio Internacional de Historia del Arte. Arte, historia e identidad en América, eds. Gustavo Curiel, Renato González Mello y Juana Gutiérrez Haces, vol. 2 (México: Universidad Nacional Autónoma de México-Instituto de Investigaciones Estéticas, 1994), 405-418.

92. Florencia, La estrella de el norte, $3 \mathrm{I}$. 
así, a mayores con la hechura de la más milagrosa efigie y de la más primorosa imagen". ${ }^{93}$

En cambio, otros autores creyeron que se trataba de san Miguel. Casi al mediar el siglo XviI, el bachiller Miguel Sánchez aseveró que aquel "ángel que representa a todos los ángeles, es el arcángel san Miguel”, y sostuvo: "En el cielo, entre todos los ángeles defensores de MARÍA, solamente se expresa y declara san Miguel [...] Piadosa consideración será, y bien fundada consecuencia, que si en el cielo se le concede aquella preeminencia y prerrogativa en causas de MARÍA, no se le había de que quitar en la tierra en una imagen tan parecida a la otra". ${ }^{94}$

Un siglo después, en el Zodiaco mariano —impreso en I755-, el padre Juan Antonio de Oviedo, al mencionar que en lo alto del Tepeyac se había edificado una capilla dedicada a la Guadalupana y san Miguel, comenta que su patrocinador creía que el ángel plasmado en el ayate de Juan Diego no es otro sino el príncipe de las milicias celestes:

pocos años ha, el bachiller don Juan Joseph de Montúfar con limosnas, que solicitó su gran devoción a esta Soberana Imagen, fabricó una hermosa capilla a la Santísima Virgen de Guadalupe, y al Príncipe de la Milicia Celestial San Miguel, creyendo, como muchos piensan, que aquel ángel que a los pies de la Imagen la sustenta, representa a San Miguel.95

En efecto, Juan José de Montúfar creía que el ángel de la Guadalupana es san Miguel, y así lo afirma en una obra suya, intitulada La maravilla de prodigios y flor de los milagros que aparece en Guadalupe, dando claro testimonio de la Concepción en gracia y gloria de María, Nuestra Señora, impresa en 1744. En la portada se lee que Montúfar es "indigno esclavo de Sr. S. MIGUeL", y en efecto, la

93. Florencia, La estrella de el norte, 34-35.

94. Miguel Sánchez, Imagen de la Virgen María Madre de Dios de Guadalupe, milagrosamente aparecida en la ciudad de México, celebrada en la historia con la profecía del capitulo doce del Apocalipsis (México: Imprenta de la viuda de Bernardo de Calderón, I648), 70 (las cursivas son mías).

95. Francisco de Florencia y Juan Antonio de Oviedo, Zodiaco mariano, en que el sol de justicia Christo con la salud en las alas visita como signos, y Casas proprias para beneficio de los hombres, lugares dedicados a los cultos de SS. Madre por medio de las más celebres, y milagrosas imágenes de la misma Señora, que se veneran en esta América Septentrional, y Reynos de la Nueva España (México: Nueva Imprenta del Real y más antiguo Colegio de San Ildefonso, 1755), 55 (las cursivas son mías). 
obra comienza con una amplia dedicatoria al príncipe de las milicias celestiales, y ahí se explica por qué en la tilma de Juan Diego no aparece ese arcángel con la vestimenta que lo distingue:

pues ni el Sol, ni la Luna, ni las Estrellas, que te adornan por el pecho [...] ni la cruz, ni las balanzas, ni la palma, que como insignias propias tuyas tiene prontas y a la mano: está el misterio, en que amante fiel y verdadero de MARía Señora Nuestra: pones tus señales en su Imagen, que aparece en Guadalupe con el sol, la luna y las estrellas. Más teniendo a MARÍA Señora (cómo vemos que la tienes a dos manos) lo tienes todo, y tus insignias más se ven más exaltadas. ${ }^{96}$

Estas opiniones tuvieron ecos plásticos. El de mayor importancia fue ideado por el propio Miguel Cabrera y llevado al grabado por Baltasar Troncoso; quizá reproducía una obra del pintor, hoy perdida (fig. 9). ${ }^{97}$ En él, el ser alado que sostiene a Guadalupe ya no es una figura infantil, sino san Miguel, quien despliega sus amplias alas, en tanto que dos angelitos sostienen con ambas manos su manto, que cubre y protege a un grupo de ángeles en el lado izquierdo y en el opuesto a los apóstoles (se identifica entre ellos a san Pedro, por dos grandes llaves que se hallan a sus pies). Debajo de san Miguel está el ser monstruoso de siete cabezas, ya vencido. La Virgen de Guadalupe en tanto, está rodeada por la Santísima Trinidad; Dios Padre y Cristo a los lados, y arriba de ella el Espíritu Santo. En ese grabado es contundente la preeminencia del príncipe de las milicias celestiales. Como ya lo ha notado Rosario Inés Granados Salinas, el grabado pretende "establecer la jerarquía de Miguel como el mayor de todos los ángeles"..$^{98}$

El grabado fue usado por otros artistas para ejecutar distintas versiones, unas más apegadas al arquetipo y otras que integraron a la composición nue-

96. Juan José de Montúfar, La maravilla de prodigios y flor de los milagros que aparece en Guadalupe, dando claro testimonio de la Concepción en gracia y gloria de María, Nuestra Señora (México: Imprenta Real y del Nuevo Rezado de Dońa María de Rivera, 1744), s.p. Posteriormente, en 175I Montúfar hizo que se publicara un sermón, predicado por Antonio Claudio de Villegas, en el que se aseguró que san Miguel es quien aparece "a las soberanas plantas de María Nuestra Reyna", y que "como su grande atlante, como su insigne y finísima columna" la sostiene, Granados Salinas, "Una travesía con olor a yauhtli", 222.

97. Granados Salinas, "Una travesía con olor a yaubtli", 222.

98. Granados Salinas, "Una travesía con olor a yaubtli", 225. 
9. Miguel Cabrera y Baltasar Troncoso, El patrocinio del arcángel san Miguel, Archivo Histórico de la Basílica de Guadalupe, caja 357, exp. 4, f. I, sección: Secretaría Capitular.

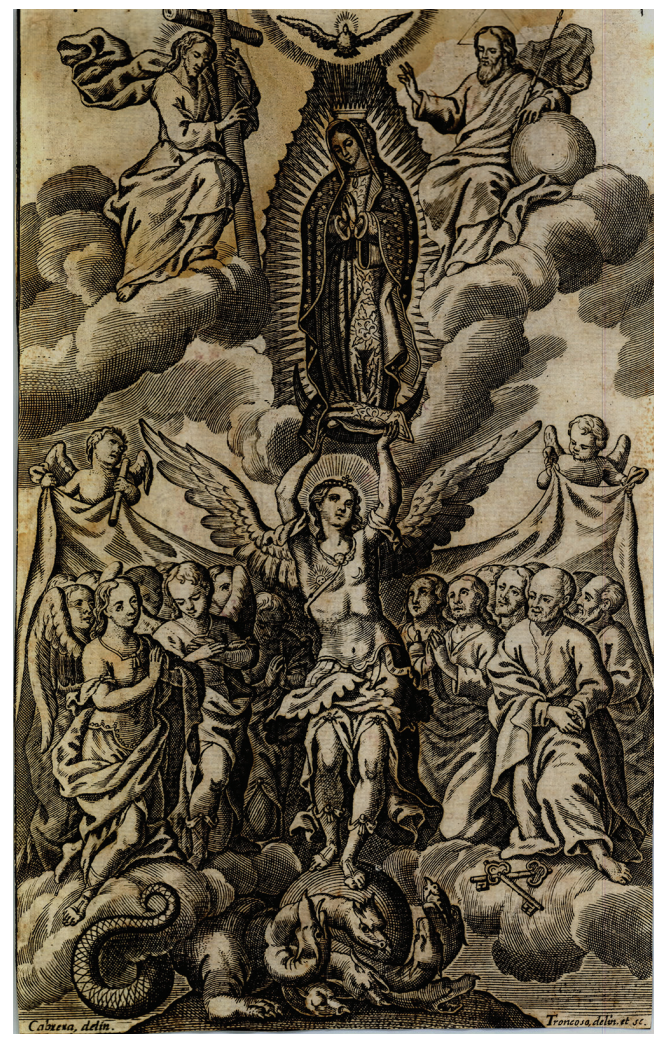

vos personajes. ${ }^{99}$ Asimismo, hay obras que si bien no reproducen la composición ideada por Cabrera, tal vez beben de ella al representar a san Miguel sosteniendo a Guadalupe. Me refiero a dos obras en particular: un nicho que se halla en la casa virreinal ubicada en la esquina de las calles de República de Argentina y Justo Sierra en el Centro Histórico de la Ciudad de México (fig. Io), y un cuadro anónimo de la colección de Rodrigo Rivero Lake, en el que Miguel, Gabriel y Rafael sostienen a la Guadalupana. En el centro está el príncipe de las milicias celestiales, con lo cual se señala su preeminencia (fig. II).

Hay indicios de que la Compañía de Jesús simpatizó con la idea de identificar al ángel de la guadalupana con san Miguel. La maravilla de prodigios y

99. Los diferentes casos son descritos por Granados Salinas, "Una travesía con olor a yaubtli", 226-230 


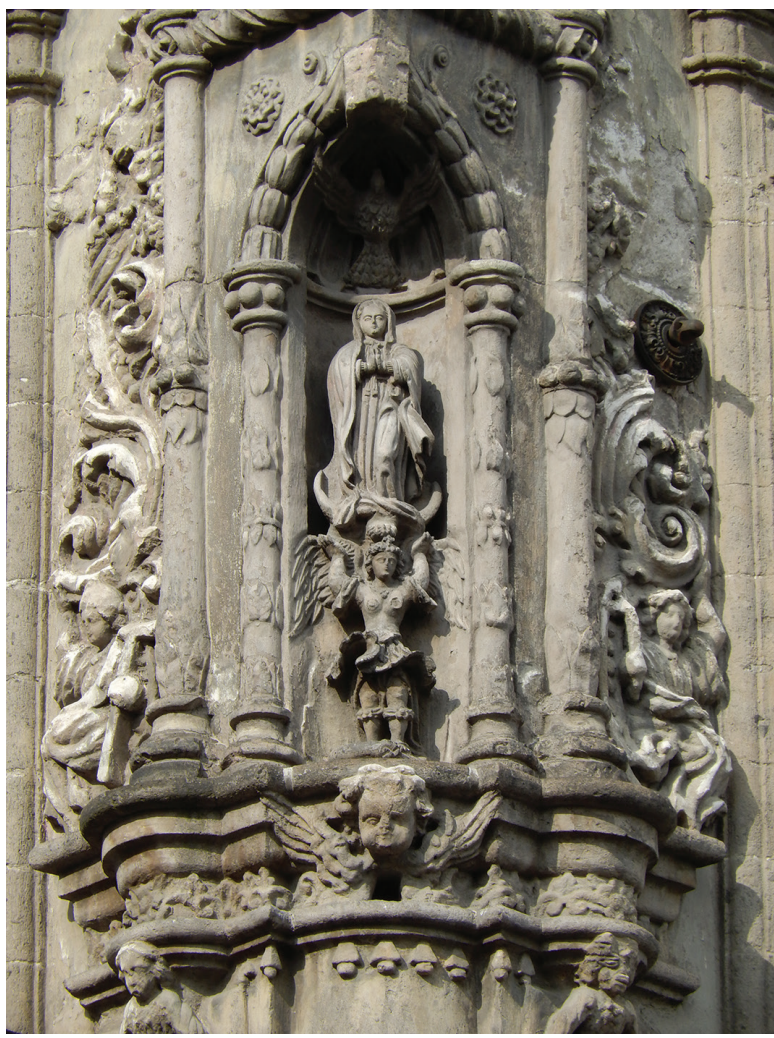

Io. La Virgen de Guadalupe y el arcángel san Miguel, nicho de la casa ubicada en la esquina de las calles de República de Argentina y Justo Sierra, Centro Histórico de la Ciudad de México, segunda mitad del siglo XVIII. Foto: Guillermo Arce. Secretaría de Cultura.-Inah. Méx."Reproducción autorizada por el Instituto Nacional de Antropología e Historia”.

flor de los milagros que aparece en Guadalupe, de Juan José de Montúfar, contiene la "aprobación" de José Maldonado, quien era catedrático del Colegio Máximo de San Pedro y San Pablo. De acuerdo con el ignaciano: "Dedica [el autor] esta obra al soberano príncipe, el Señor San Miguel, aplicándole su afecto, a que este gloriosísimo serafín es el que mantiene el hermoso simulacro", es decir, la Virgen estampada en la tilma. ${ }^{100}$ En La maravilla hay además un "parecer" firmado por un jesuita al que ya me he referido líneas atrás: el padre Juan Antonio de Oviedo, quien afirma no haber hallado en ese "librito" —así le llama- "cosa alguna en qué tropezar, ni en lo que toca a nuestra Santa fe, ni en lo que mira a las buenas costumbres, antes si muchos eficaces motivos

Ioo. Montúfar, La maravilla de prodigios, s. p. 
II. Anónimo novohispano, La Virgen de Guadalupe con la Santísima Trinidad, los arcángeles Miguel, Gabriel y Rafael, ángeles músicos y Juan Diego, I787, óleo sobre tela, colección Rodrigo Rivero Lake. Foto: Guillermo Arce.

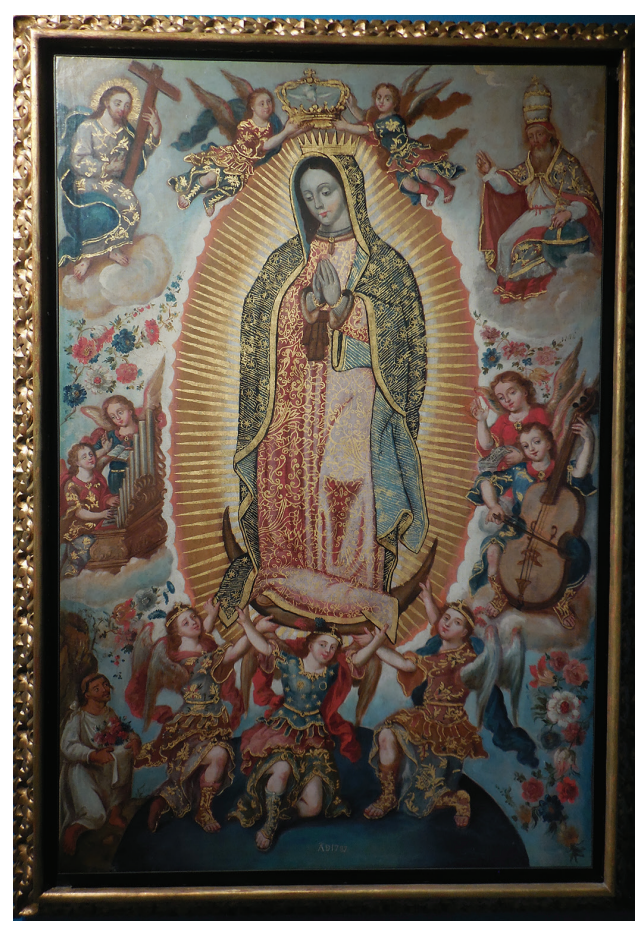

que alienten a la devoción de Nuestra Señora y de Señor San Miguel". ${ }^{\text {Ior }}$ Distintos historiadores del arte que han abordado la obra de Miguel Cabrera han llamado la atención sobre la relación del pintor con los jesuitas, puesto que él trabajó en diferentes obras promovidas por ellos. De hecho, se ha considerado que la Compañía de Jesús fue uno de los tres grandes protectores de Cabrera (la colegiata de Guadalupe y el arzobispado fueron los otros dos). ${ }^{\text {IO2 }}$ La relación del pintor con dicha orden religiosa, de acuerdo con Verónica Zaragoza, inició entre 1747 y $1749,{ }^{\mathrm{IO} 3}$ y se ha concluido que el pintor conoció a ignacianos prominentes como el propio Juan Antonio de Oviedo, a quien retrató ya

IoI. Montúfar, La maravilla de prodigios, s. p.

IO2. Luisa Elena Alcalá, "Miguel Cabrera y la congregación de la Purísima", Anales del Instituto de Investigaciones Estéticas XXXIII, núm. 99 (20II): I3I-I32.

I03. Verónica Zaragoza, "Miguel Cabrera y la Compañía de Jesús", en Miguel Cabrera. Las tramas de la creación (México: Instituto Nacional de Antropología e Historia, 2015), I7. 
muy anciano. ${ }^{\mathrm{I04}}$ Las relaciones de Cabrera con los jesuitas fueron más allá del simple trato artista-cliente, pues el artista fue miembro de la congregación de la Purísima, lo cual ha sido prácticamente demostrado por Luisa Elena Alcalá. Esa congregación fue "la hermandad religiosa de mayor prestigio entre las que la Compañía de Jesús regentaba en México y una de las más respetadas de la ciudad". ${ }^{105}$ De acuerdo con la citada autora, Cabrera "a través de dicha hermandad pudo cristalizar en parte relaciones con miembros importantes de la Compañía y personajes ilustres de la sociedad novohispana”. ${ }^{\text {Io6 }}$

Miguel Cabrera plasmó en el manifestador sus inquietudes en torno a la Virgen de Guadalupe. Ciertamente, es incuestionable que Cabrera fue uno de los grandes difusores de la opinión del bachiller Montúfar a través del grabado ya mencionado y mediante el manifestador del retablo mayor de Tepotzotlán. Por todo lo que sabemos sobre Cabrera, es posible afirmar que no hubo otro artista en la Nueva España que por medio de su obra difundiera tal creencia.

\section{Conclusión}

Una de las paradojas de este trabajo ha sido haberse adentrado en una de las funciones de los retablos — la exposición de la hostia consagrada — a través del retablo mayor del templo del noviciado de Tepotzotlán, que como ya se dijo es uno de los retablos novohispanos más conocidos, tanto para investigadores como para público no especializado. Ello ha hecho evidente que la presencia del Santísimo Sacramento ha sido escasamente valorada por los investigadores del arte virreinal. Prácticamente nadie había señalado cuál había sido la ubicación de los "siete príncipes" mencionados en el contrato, a pesar de que dicho documento fue publicado por Guillermo Tovar de Teresa hace tiempo —en I98I- y de que las seis peanas que están a los lados del manifestador aún subsisten.

Para seguir ahondando en la importancia tanto del "depósito" como del "manifestador" será preciso explorar nuevos casos. Será un reto, pues son escasos los retablos virreinales que como el retablo mayor de Tepotzotlán aún

I04. Sobre ese retrato, llevado al grabado por Baltasar Troncoso, véase el artículo de Alcalá, "Miguel Cabrera", III-I36.

I05. Alcalá, "Miguel Cabrera", I23.

ı06. Alcalá, "Miguel Cabrera”, i22. 
DOI: http://dx.doi.org/10.22201/iie.18703062e.2019.114.2667

conservan el sitio que se usó para manifestar el Santísimo Sacramento. En gran medida, la investigación deberá realizarse sobre retablos desaparecidos. Para ello, será necesario leer con atención y cautela las descripciones de retablos en fuentes documentales como los contratos. A pesar de las dificultades que implica estudiar obras desaparecidas, se trata de un trabajo tanto imprescindible como necesario. \$s 